Article

\title{
Discriminating People's Attitude towards Building Physical Features in Sustainable and Conventional Buildings
}

\author{
Marco Caniato * (D) and Andrea Gasparella \\ Faculty of Science and Technology, Free University of Bozen-Bolzano, Bozen 39100, Italy; \\ andrea.gasparella@unibz.it \\ * Correspondence: marco.caniato@unibz.it
}

Received: 7 March 2019; Accepted: 10 April 2019; Published: 13 April 2019

check for updates

\begin{abstract}
At the present time, buildings technologies for residential constructions are essentially divided into two groups. The first one is associated to conventional techniques using concrete, masonry or in general heavyweight structures, while the second one is associated to timber, e.g., sustainable glulam, crosslam, etc. (lightweight structures). Technicians, scientist, designers and non-expert people have their own stereotyped ideas and attitudes, related to thermal and sound insulation, structural stability, fire resistance, service equipment, heating and cooling systems, etc. Nevertheless, for people who is not strongly related to both construction procedure studies, analysis, experiences or focuses, timber structures appear to be more comfortable, reliable and insulated. The need of investigating the role of non-physical and non-measurable parameters in affecting future inhabitants' overall preconceptions related to new sustainable buildings is thus of paramount importance. The hypothesis that behavioral, physiological, past experiences and psychological factors can have a non-negligible role in determining the final user perception, interaction and adaptation to timber buildings has to be verified. For these reasons, an international survey was realized in order to investigate what individuals expect from these two different construction technologies. After focused statistical analysis, it could be demonstrated how geographical difference could influence results and that, for indoor comfort, stereotypes do exist for lightweight buildings in comparison to heavyweight ones, highlighting how timber construction are associated to thermal comfort and sensed as innovative even if there is no complete distrust in conventional ones. The influence of non-physical and non-measurable parameters is correlated to people's attitudes.
\end{abstract}

Keywords: energy efficiency and acoustics; indoor whole comfort; survey and questionnaire; timber buildings; green buildings; perception; occupants; inhabitants

\section{Introduction}

At present, indoor comfort is one of the most highly rated parameters for the built environment. Buildings are part of everybody's life and their role is to protect us from outdoor climate conditions. Many different construction techniques are currently available, including concrete or masonry with additional layers, steel components with precast panels, timber composite structures, etc. As a matter of fact, they can be divided in two groups: heavyweight and lightweight constructions.

Historically, numerous buildings were constructed using a plastic material readily available in nature: wood. After the use of gravels and concrete began to spread timber construction was increasingly disregarded for a period of time. Nevertheless, in recent years the Kyoto Protocol [1] has pushed to limit $\mathrm{CO}_{2}$ emissions in every production are. The use of sustainable materials is now definitely being stimulated worldwide [2-7], because they can store carbon dioxide, both in renovated 
and in new edifices [8-10]. The advantages of using sustainable materials are now confirmed by various scientific studies [11-13]. Environmental rating systems or protocols [14-16] can stimulate both non-experts and building industry employees [17] to focus on indoor comfort and sustainable construction procedures.

In this view, the production of timber buildings represents an alternative to heavyweight constructions. It was recently demonstrated [18] that wood is the most widely used forest product for construction; it is also shown that this material has excellent mechanical properties, good life expectancy and high specific heat $[19,20]$. Hence, gradually lightweight timber edifices are growing both in unity and level numbers, evolving from one to multi-story buildings.

They present secure advantages like higher quality, monitored industrial process, controlled and reusable waste production, transport optimization and very good performance [21]. However, the disadvantages are mainly related to low mass, causing: (i) reduced sound isolation with regard to low-frequency components [22-24], (ii) limited thermal inertia [25,26] and (iii) structural restrictions when high rises or wide spans are required [27-29]; another issue is the non-standardization of the construction technologies (crosslam, glulam, timber-concrete, timber-frame open-truss, etc.) [30,31].

Both construction technologies are assembled by means of very similar insulating layers [32-34], but achieving different performances [35-39]. For example, outdoor noise sources or other disturbing factors could affect measured results [40,41].

Based on the above reported considerations, there is no clear consensus on the relevance of green construction solutions related to the perception and preferences of non-expert people. It seems quite difficult to predict how future inhabitants would perceive the quality and performance of sustainable timber buildings. This task requires considering many different aspects simultaneously. Consequently, final goal of this research is to implement a precise, multi-physics and multi-objective assessment of people's impressions, ideas and stereotypes correlated to timber buildings compared to heavyweight conventional ones. Indeed, the comparison between heavyweight conventional buildings and lightweight sustainable timber ones represents an original contribution of this work. It is a common habit in Brazil [42], Europe [43] and US [44] and to live in conventional heavyweight houses, which provide low indoor comfort, old conditioning systems and noisy spaces. In fact in the past there was a lack of attention on buildings thermal and acoustic insulations or on efficient conditioning systems installation. In recent years, people are often moving into modern sustainable timber buildings and frequently they have preconceptions about these constructions in terms of performances and conditioning systems user-friendliness.

In particular, this contribution focuses on understanding future inhabitants' expectations in a holistic way, comprehending energy saving performances, acoustic comfort and insulation, structural stability, fire hazard, mold resistance, conditioning systems, etc. To this aim, a four-section survey was developed, each containing several question related to personal expectation on different buildings performances topics, always comparing conventional and timber ones.

A more specific goal is to understand why there are some stereotypes related to thermal or acoustic insulation, indoor comfort and heating technologies. The hypothesis that a bias exists on perspective occupant's expectations, originated by behavioural, physiological, psychological factors and past experiences is verified. This is of crucial importance, as it can play a significant role in determining end-users' perceptions of comfort, interaction and adaptation to timber buildings and thus may have a noteworthy influence on the final sensations of the inhabitants.

To this aim, subjective survey campaigns were carried out involving non-expert people. Collected data were used to understand and compare non-expert people opinions, impressions and preconceptions, both about heavyweight (conventional) and lightweight (timber) buildings. Personal-sociological variables are considered and taken into account. In fact, the consideration of (non-measurable) psychological factors provides a much more comprehensive analysis of human preconception of the indoor environment, clarifies human-based behaviour related to new sustainable buildings [45]. 
The final goal of the study is to demonstrate the necessity to consider non-physical parameters in addition to the measurable ones, when evaluating inhabitants' responses within the built environment and to provide a holistic evaluation, based on subjective perceptions of building physics parameters. Consequently, this research provides a clear comprehension related to people reaction to buildings physics aspects, both related to conventional and timber constructions.

To these aims, the paper reports in Section 2 a literature review, highlighting the knowledge gaps, and in Section 3 the detailed description of the research methodology, including the focus on questionnaire structure and people selection. In Section 4, results of the survey divided into Italian and International results as well as statistical analysis were reported, while in Section 5 a detailed discussion of the results is presented.

\section{Literature Review and Knowledge Gaps}

From the indoor comfort point of view, many papers in the scientific literature are related to buildings' interior well-being. In order to understand how many works are correlated to inhabitants perception and to non-expert stereotypes, a literature survey was carried out using the Scopus [46] (step A) and Google Scholar [47] (step B) databases. A scheme of the adopted process is reported in Figure 1.

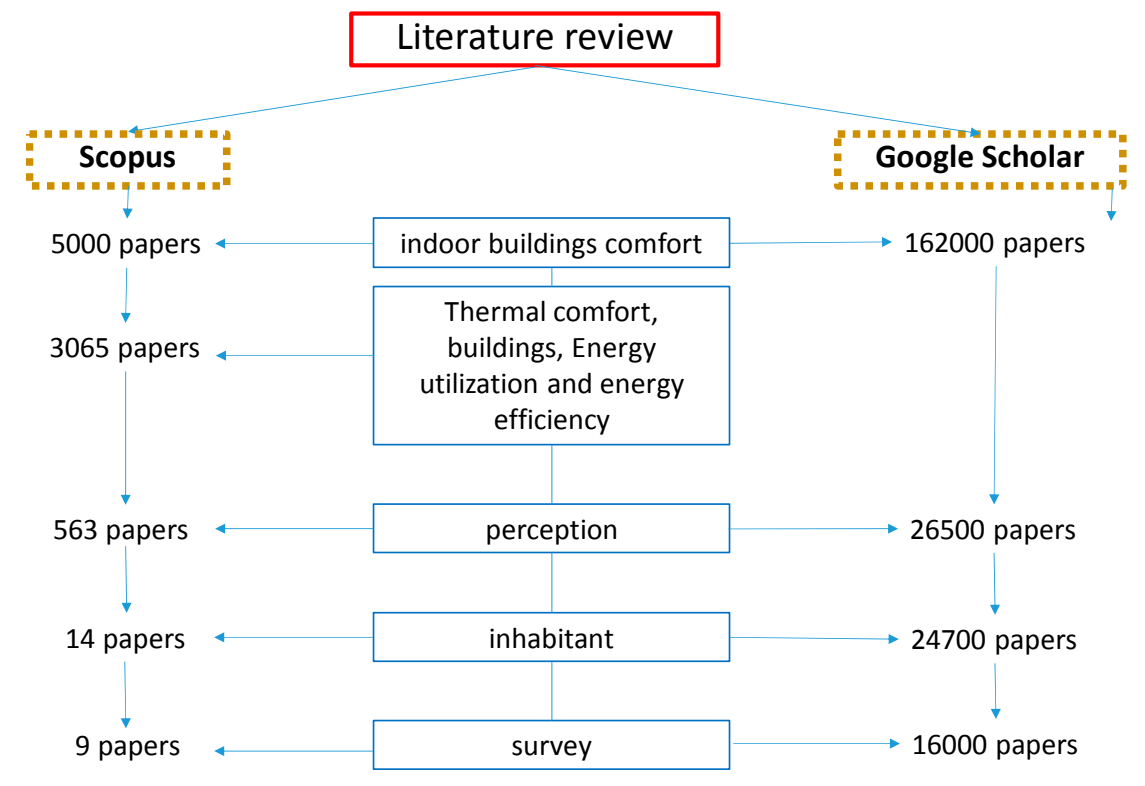

Figure 1. Literature review scheme.

For step A, using the keywords "indoor buildings comfort" more than 5000 results were found in the research (phase 1). Refining this outcome and limiting the search to "Engineering, social science, energy" as field and "thermal comfort, buildings, energy utilization and energy efficiency" as keywords, the results decreased to 3065 (phase 2). Searching within these results using the keyword "perception", shortened the list to 563 papers (phase 3), but if the limit "inhabitant" is also imposed (phase 4a) only 14 records are included and only nine of them are based on surveys.

After completing the list of studies, a comprehensive review was carried out. Within these nine, only four studies used questionnaires to investigate peoples' responses regarding personal perceptions of comfort in specified buildings or situations.

Only one review was found [48], dealing with social houses' environmental comfort and concluding that retrofits present the possibility to improve well-being, but there have also been cases in which they increase pollutant concentrations. No differences in terms of lightweight timber and heavyweight conventional buildings were found. In their paper, Gupta and Chandiwala [49] used a questionnaire in order to investigate occupant's feedback related to pre- and post-refurbishment of houses, pointing 
out that non-expert feeling, stereotypes and opinions change the energy efficiency and comfort results. In another study, Isaacs et al. [50] used subjective surveys administered to non-expert people in order to understand their living habits, relating them to indoor comfort. Zhang et al. [51] used subjective surveys to compare results with field measurements.

If in the step A and phase 4a the keyword "inhabitants" is changed for "subjective" (phase 4b), the hits increase to 210. Subsequently, the keyword "survey" (phase 5) was used to further limit the query. A total of 141 papers was found but when the keyword "timber" (phase 6) is used only one paper is listed and unfortunately it was not related to the aim of this research.

Going back to phase 5, many papers are related to specific case studies (101 results). For example Castaldo et al. evaluated employees' wellbeing and comfort perception using subjective surveys to investigate non-physical parameters [52], Yang et al. focused on school occupancy [53], Kotopouleas and Nikolopoulou focused on an airport environment [54].

In step B, the same procedure were used. In phase 1, 162,000 results were found. Since Google Scholar does not allow the same categories as Scopus, phase 2 was skipped. Results for phase 3 were listed as 26,500, and conversely for phase $4 \mathrm{a}$ the list was composed of 24,700 records. In phases $4 \mathrm{~b}$ and 5 the results decreased to 24,000 and for phase 6 they went down to 16,500. This huge amount of studies seems too inclusive; as a matter of fact, it was not possible to limit their relevance related to keywords. Thus, only the first three pages of results (75 results) were considered as relevant and, within them, only two other articles were related to the present investigation. Gou et al. [55] focused on a comparison between green buildings and other types, using occupant satisfaction surveys, highlighting that the best green buildings tended to be better than the best conventional ones. On the other hand, Paul and Taylor [56] compared occupant satisfaction between green and conventional buildings. They concluded that all aspects of comfort, including aesthetics, serenity, lighting, ventilation, acoustics and humidity, were not likewise felt by inhabitants related to different edifice typologies. In the end, their conclusions highlighted that no differences were found between green and traditional constructions in terms of occupant's comfort and gratification by means of subjective surveys. In their very recent paper, Sant'Anna et al. [42] outlined that employees have a better feeling of areas within sustainable edifices compared to employees in traditional ones.

Actually, most of the papers deal with the comparison between green and conventional buildings through occupants' perceptions and there is no agreement between the final results. On the other hand, no research was conducted firstly on non-expert's expectation, regarding new sustainable buildings without living inside them. Furthermore, no explorations containing comparisons between conventional heavyweight buildings and lightweight timber building were presented.

\section{Materials and Methods}

Surveys are feedback techniques performed to develop a study [57]. They are very important because they allow interviewed residents, non-expert or inhabitants to reflect on a series of conditions related to the house within a pre-prepared procedure, easy to comprehend [58]. Multiple-choice or scale-based responses explain the sense and framework of the posed questions [59,60]. More than 400 participant responses were collected and elaborated, out of the 800 personal invitations to contribute to the survey. On the very first page of the questionnaire, a disclaimer was added describing the motivation of the research clearly requesting that only non-expert peoples' opinions were of interest for this work.

A web-based questionnaire was administered to non-expert people in several countries, including ones in Europe, Asia, Africa and Australia (Figure 2). Voluntary responses to the surveys were collected; the participants declared that they did not live in a timber building. The use of a web-based survey has many pros (economy, speed, worldwide distribution), but it is impossible to get in touch with respondents, so it was not possible to acquire socio-cultural aspect data; furthermore, adding more questions on these topics would transform the questionnaires into a very long survey. It is demonstrated that surveys with more than 10 questions are not reliable, because people after the 10th 
claim start to respond always with middle range values, because of annoyance, etc. or (even worse) they abandon the survey before the end [58].

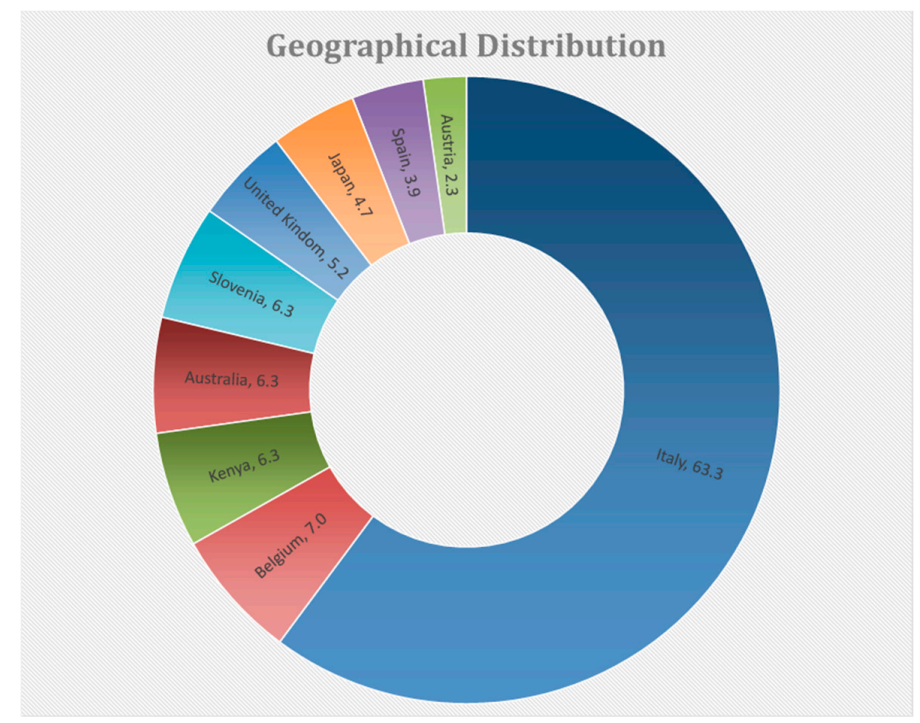

Figure 2. Geographical distribution of web-based surveys (percentage values).

The sample is described here, distinguishing between Italian (Part 1) and International (Part 2) results. With respect to the considered sample, Part 1 respondents' ages varied as follows:

- $\quad 28 \%$ were less than 34 years old;

- $61 \%$ were less than 50 years old and;

- $11 \%$ were less than 70 years old.

The respondents were $48 \%$ females and $52 \%$ males, so there is almost an equal gender proportion. Moreover, the education levels achieved by participants were mainly a master degree diploma (49\%) followed by secondary school diploma $(19 \%)$, bachelor degree $(17 \%), \mathrm{PhD}$ or postgraduate $(14 \%)$ and middle school (1\%). For part 2, the respondents' ages varied as follows:

- $51 \%$ were less than 34 years old;

- $30 \%$ were less than 50 years old;

- $19 \%$ were less than 70 years old.

The respondents were $67 \%$ females and $33 \%$ males, so there was a larger women's participation. Additionally, the education level achieved by respondents was mainly a master degree diploma (41\%) followed by bachelor degree (28\%), PhD or postgraduate (21\%), secondary school diploma (19\%) and no middle school.

\section{Description of the Questionnaire}

The questionnaire is divided into four parts related to: (i) general topics, (ii) structural materials' impact, (iii) influence of conditioning technologies and (iv) design properties. In Tables 1 and 2 the description of the questionnaires is reported. The main goal was to examine what people consider about each single aspect, comparing conventional and timber non-expert peoples' biases. In fact timber structures are generally sensed as modern, positive and environmentally-friendly edifices, while conventional ones are assessed as old-fashioned and pollutant buildings.

Some questions (like insulation from rain, healthy indoor environment, fire resistance) were introduced only with sole purpose to distract people's attention from the key examination items, namely thermal and acoustic insulation, service equipment influence and thus to gain non-artificial replies (concerning buildings' physical parameters). 
Table 1. Questionnaires' 5-points Likert-type scale for (i) general topics and (iv) design properties.

\begin{tabular}{ccc}
\hline Value Scale & Evaluation & Tendency \\
\cline { 1 - 2 } 1 & Very important & Positive tendency \\
\hline 2 & Important & \\
\hline 3 & Irrelevant & Neutral tendency \\
\hline 4 & Not so important & Negative tendency \\
\hline 5 & Not at all important & \\
\hline
\end{tabular}

Table 2. Questionnaires' 5-points Likert-type scale for (ii) structural materials impact and (iii) conditioning technologies.

\begin{tabular}{ccc}
\hline Value Scale & Evaluation & Tendency \\
\hline 1 & Completely agree & Positive tendency \\
\hline 2 & Agree & \\
\hline 3 & Irrelevant & Neutral tendency \\
\hline 4 & Only partly Agree & \multirow{2}{*}{ Negative tendency } \\
\hline 5 & Completely disagree & \\
\hline
\end{tabular}

A subjective survey based on semi-enclosed questionnaires with a 5-points Likert-type scale was developed. Only one answer per line was allowed. Likert-type scales are a frequently utilized technique to grade responses in subjective questionnaires. Respondents identify their agreement or disagreement levels on a symmetric agree-disagree scale for a sequence of pronouncements. Thus, the range computes the concentration of their emotive state for a specified issue or declaration [61]. No differences were introduced for the International and Italian questionnaires. The survey design was also based on previous similar studies [52,62-64]. In Tables 1-3 an outline of the questionnaire is reported for the case of timber buildings. The one for conventional buildings is exactly the same.

Table 3. Questionnaires: topics and issues included for timber construction.

\begin{tabular}{|c|c|c|}
\hline Index & Question & Min.-Max. \\
\hline \multirow{8}{*}{ General topics } & Acoustic insulation & $1-5$ \\
\hline & Thermal insulation & $1-5$ \\
\hline & Structural stability & $1-5$ \\
\hline & Durability & $1-5$ \\
\hline & Insulation from rain & $1-5$ \\
\hline & Resistance to mold & $1-5$ \\
\hline & Healthy indoor environment & $1-5$ \\
\hline & Sustainability & $1-5$ \\
\hline \multirow{4}{*}{ Structural materials impact } & Wood creates a comfortable home environment & $1-5$ \\
\hline & Wood ensures thermal insulation & $1-5$ \\
\hline & Wood ensures acoustic insulation & $1-5$ \\
\hline & Wood ensures structural stability & $1-5$ \\
\hline \multirow{5}{*}{ Conditioning technologies } & The heating system comes with a number of radiators & $1-5$ \\
\hline & Radiant heating is used (e.g., floor heating) & $1-5$ \\
\hline & Warm air is used to heat the building & $1-5$ \\
\hline & No heating is needed & $1-5$ \\
\hline & Windows need not be opened & $1-5$ \\
\hline \multirow{5}{*}{ Design properties } & Properly designed thermal insulation & $1-5$ \\
\hline & Properly designed acoustic insulation & $1-5$ \\
\hline & Properly designed fire-proof structures & $1-5$ \\
\hline & Structural design & $1-5$ \\
\hline & Turnkey project delivery & $1-5$ \\
\hline Personal data (education, age, gender) & Individual characteristics & nominal \\
\hline
\end{tabular}


In order to evaluate single item impact within every group, both for timber and conventional buildings separating Italian and International results, a percentage study is reported. Then inferential analysis were used to better understand significant parameters and possible item correlations.

To these aims, for the first step a parametric analysis was used (average) which could provide numerical results comparing constructions technologies and highlighting the best-rated and worst-rated item for single group. Furthermore, this methodology could provide separated Italian and International results. For the second step, a non-parametric test (Mann-Whitney U procedure) was used in order to outline significant differences between timber and conventional buildings separating Italian and International results.

Furthermore, the two previous analysis were compared and only the significant differences between timber and conventional buildings were taken into account, merging Italian and International results. The resulted items were then analysed with Spearman's $\rho$ test, in order to understand if possible correlations between items are present.

\section{Results}

For every answer, a percentage comparison is reported. In order to understand if regional origin is relevant, the Italian outcomes were separated from the International ones, with specific sections. Then a statistical analysis is presented. The internal reliability of the questionnaires has been calculated by means of the Cronbach's alpha. Results indicated 0.96, suggesting a strong internal consistency of this instrument.

\subsection{Italian Percentage Results}

The answers from the Italian group (Figure 3), highlight that general requirements importance differs for thermal and acoustic insulation; for the first one, almost everyone thinks that is very important for both technologies, while for acoustic insulation only half of the sample believed that this is a significant aspect. In both cases, the comparison between lightweight and heavyweight gives almost the same percentage results.
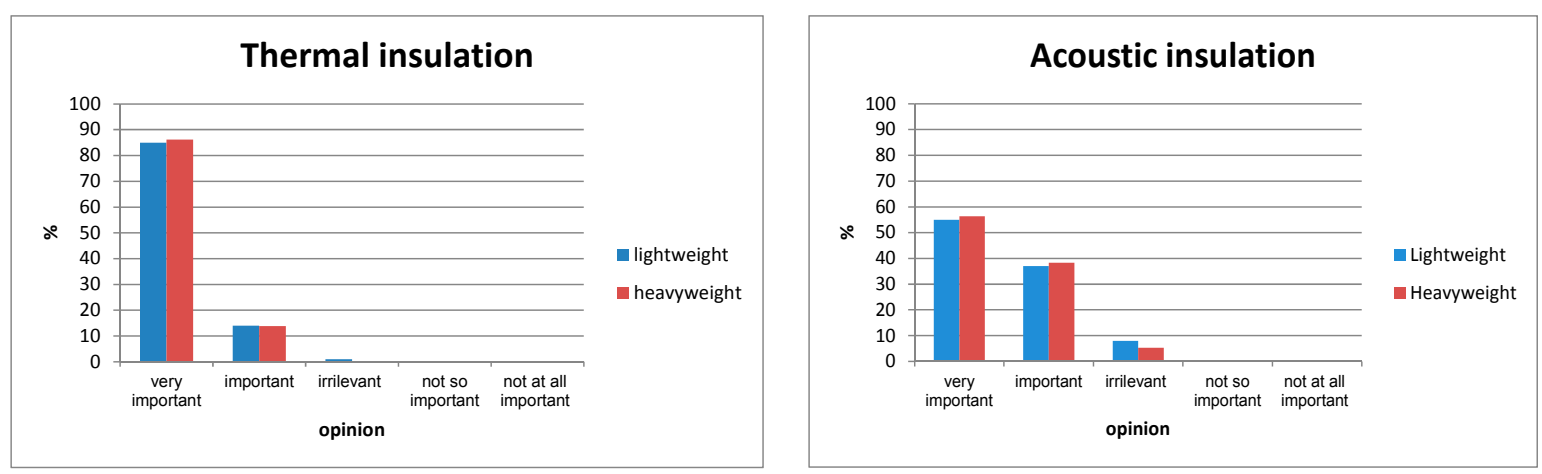

Figure 3. Italian results-Relevance of thermal and acoustic insulation performance.

About structural stability and time influence (durability, Figure 4), the general opinion is that those are very important for non-expert people as they expect the same performance from both technologies. This is very important related to "time influence", because one of the typical stereotype related to timber structures is that they cannot last in years as much as their "conventional" competitors. 

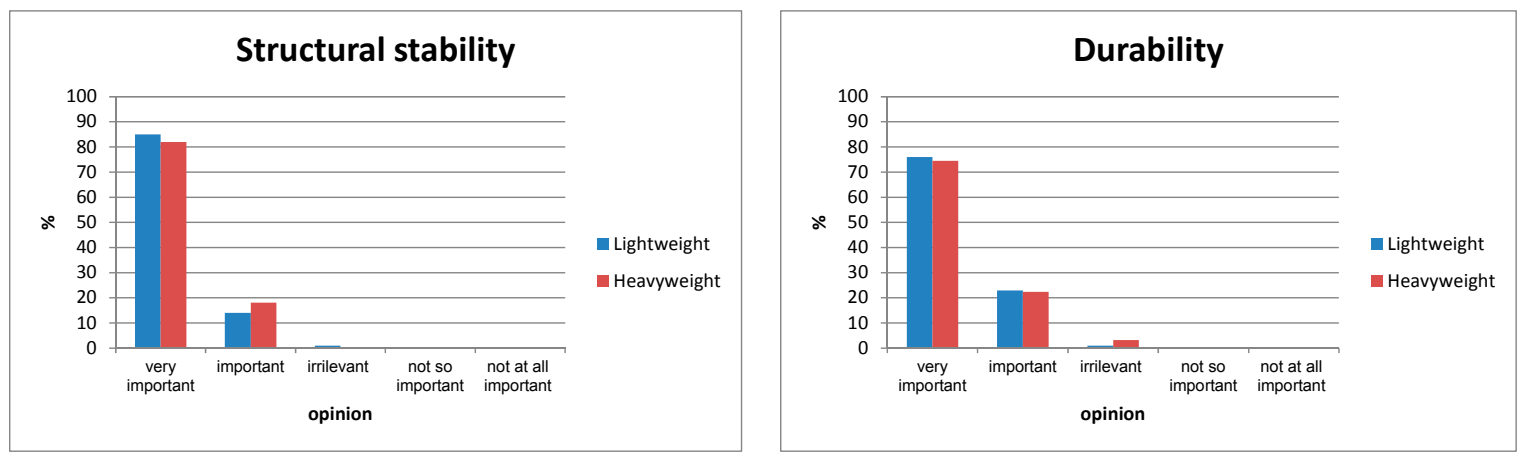

Figure 4. Italian results-Relevance of structural stability and durability performance.

In Figure 5, the water (rain and mold) resistance is highlighted. Here a difference is evident referring to rain insulation: for the heavyweight structures the interest is less than for the lightweight ones. This could be related to the stereotype that timber structures are not as good as heavyweight ones to resist to water.
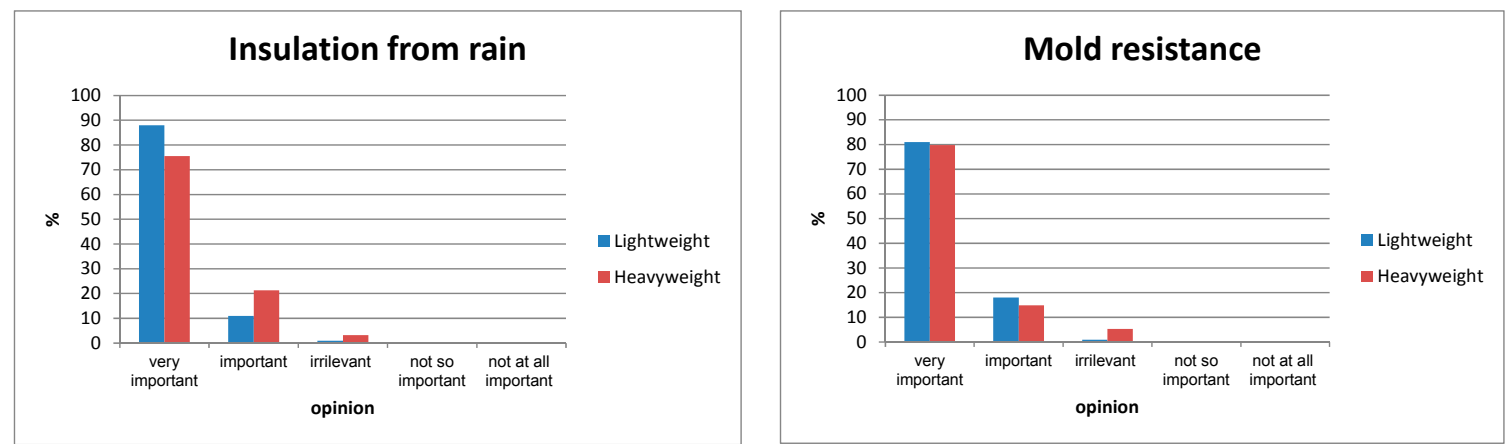

Figure 5. Italian results—Relevance of water (rain and mold) resistance performance.

In Figure 6, the indoor health and eco-compatibility topic were analysed. People seem to expect the same general features from both lightweight and heavyweight buildings. In particular, people expect the same performance from both technologies and would not chose the timber one in terms of environmental impact, even if there seems to be less interest in this performance aspects.
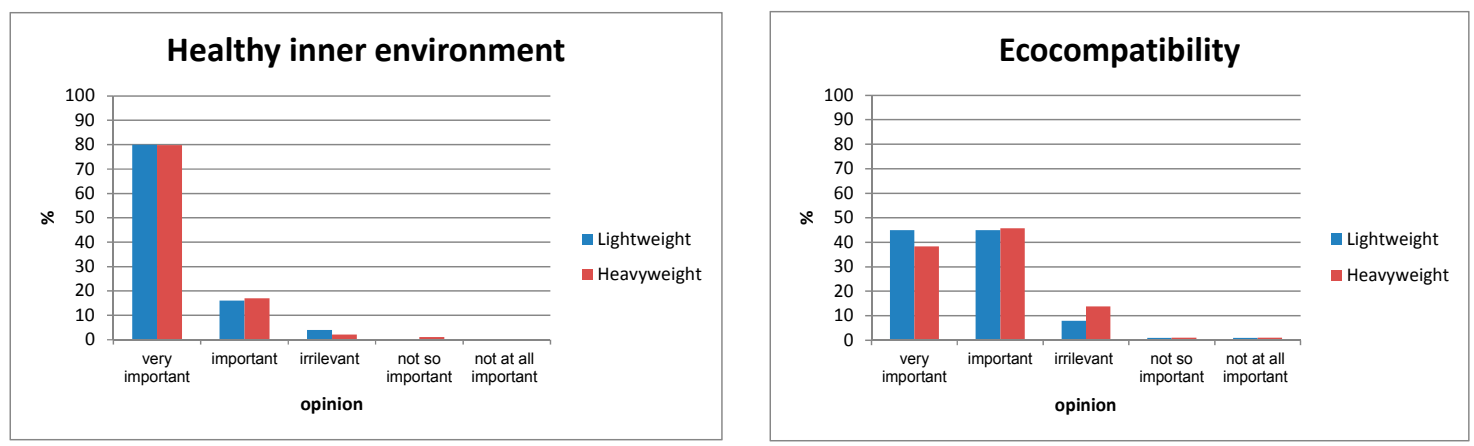

Figure 6. Italian results-Relevance of health and eco-compatibility performance.

Figure 7 reports the attitudes on materials' effects. It is highlighted how there is no uniform pattern. Wood is supposed to offer a comfortable effect to indoor volumes and the timber assembly is quite imagined to assure thermal protection. Conventional heavyweight materials seems not to provide comfort and not to contribute to create a comfortable home environment. It is evident how the use of wood is perceived as the main cause of the indoor comfort. On the hand, acoustic insulation is not related to the structure. 


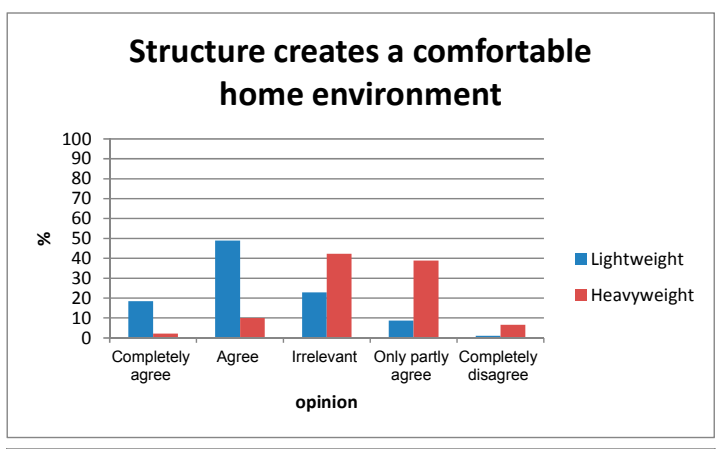

Material of structure ensures acoustic insulation

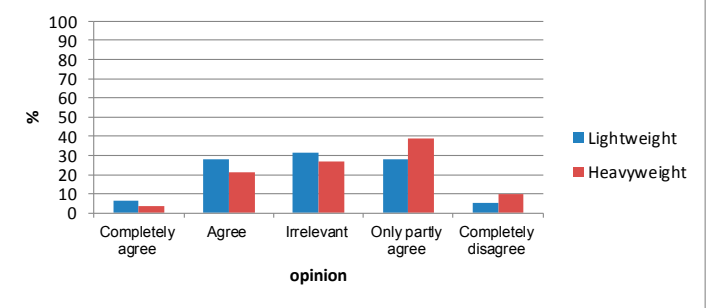

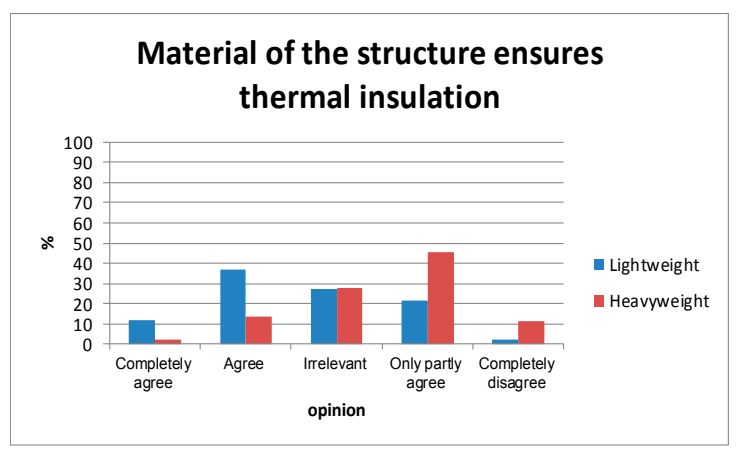

Material of the structure ensures structural stability

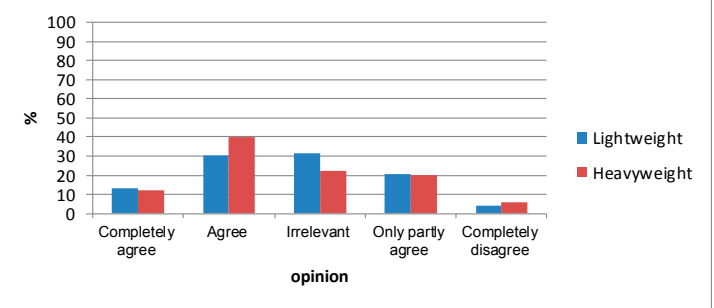

Figure 7. Italian results-Relevance of the influence of the materials.

Figure 8 reports the responses on the conditioning aspects. Here, it is depicted that radiators are more associated to conventional heavyweight edifices. Nonetheless, radiant or air technologies, are related to both categories of buildings. This demonstrates how nowadays service equipment is changing in our houses. However, the topic "no heating" is not reputed as impossible in any case. In conventional houses as well as for timber buildings it is not excluded at all.
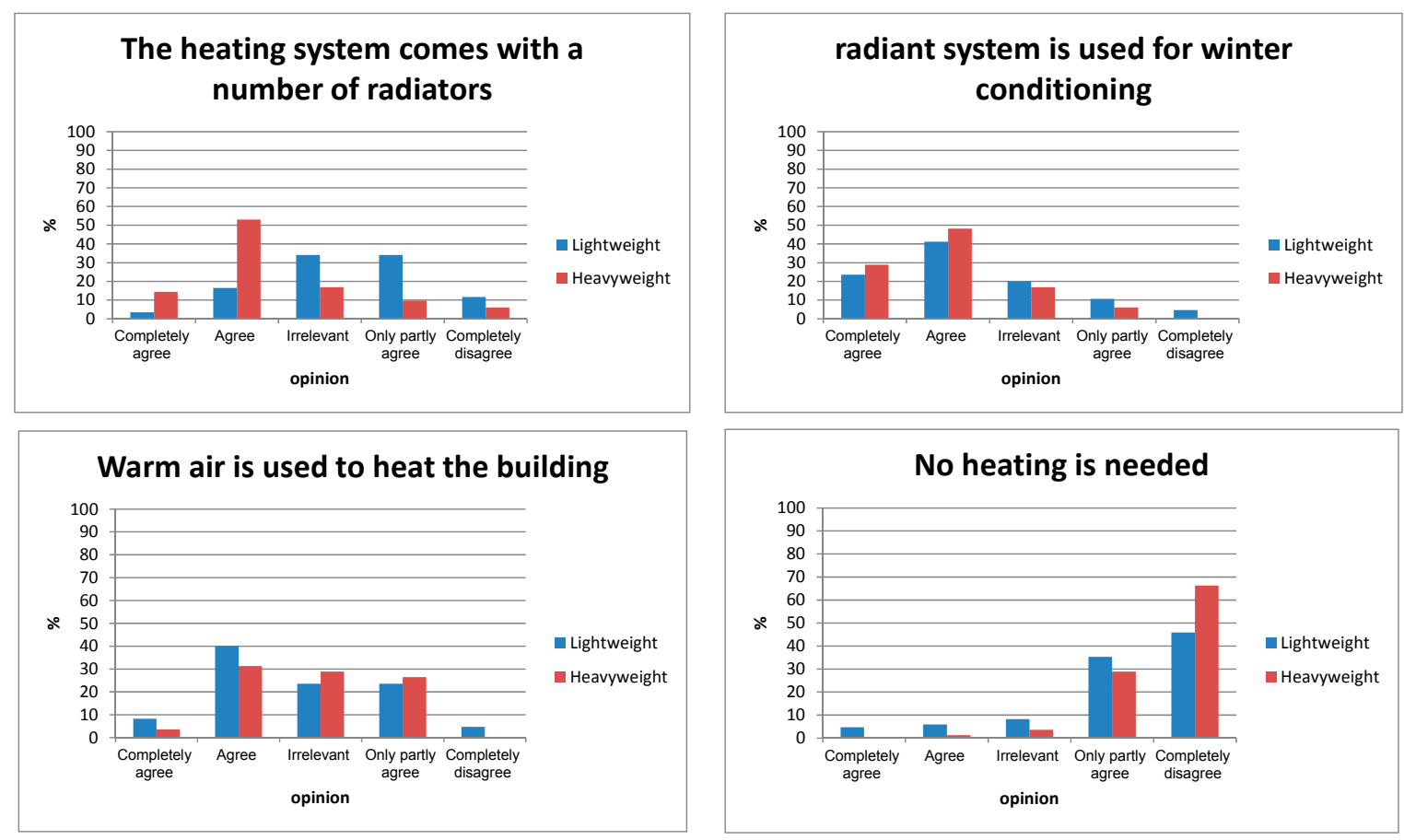

Figure 8. Italian results—Relevance of the influence of the conditioning technologies.

In Figure 9, the opinion on the issue "there is no need to open windows" is reported. It is clear how people is not ready yet to cope with high energy saving buildings and have to be deeply educated about this paramount topic. In fact, in this kind of building a high thermal insulation performance is 
expected (see Figure 2), but no such results could be obtained if a good mechanical ventilation with heat exchange isn't present.

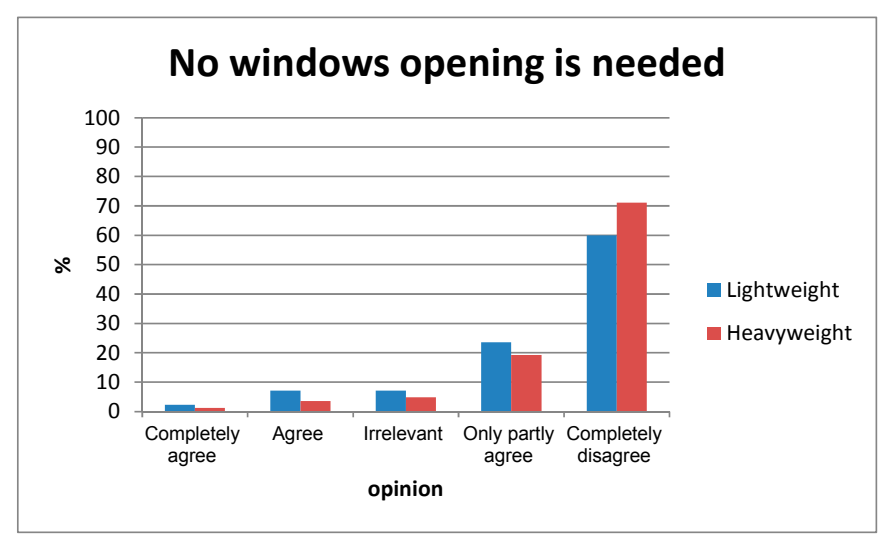

Figure 9. Italian results-Opinion on window opening needing.

In Figure 10, the attitudes the design topic are described. Thermal insulation is the greatest graded aspect in both construction technologies, in spite of acoustic protection. The comparison shows similar trends, except for fire resistance. Here, it is believed that a proper design is needed for timber structures.
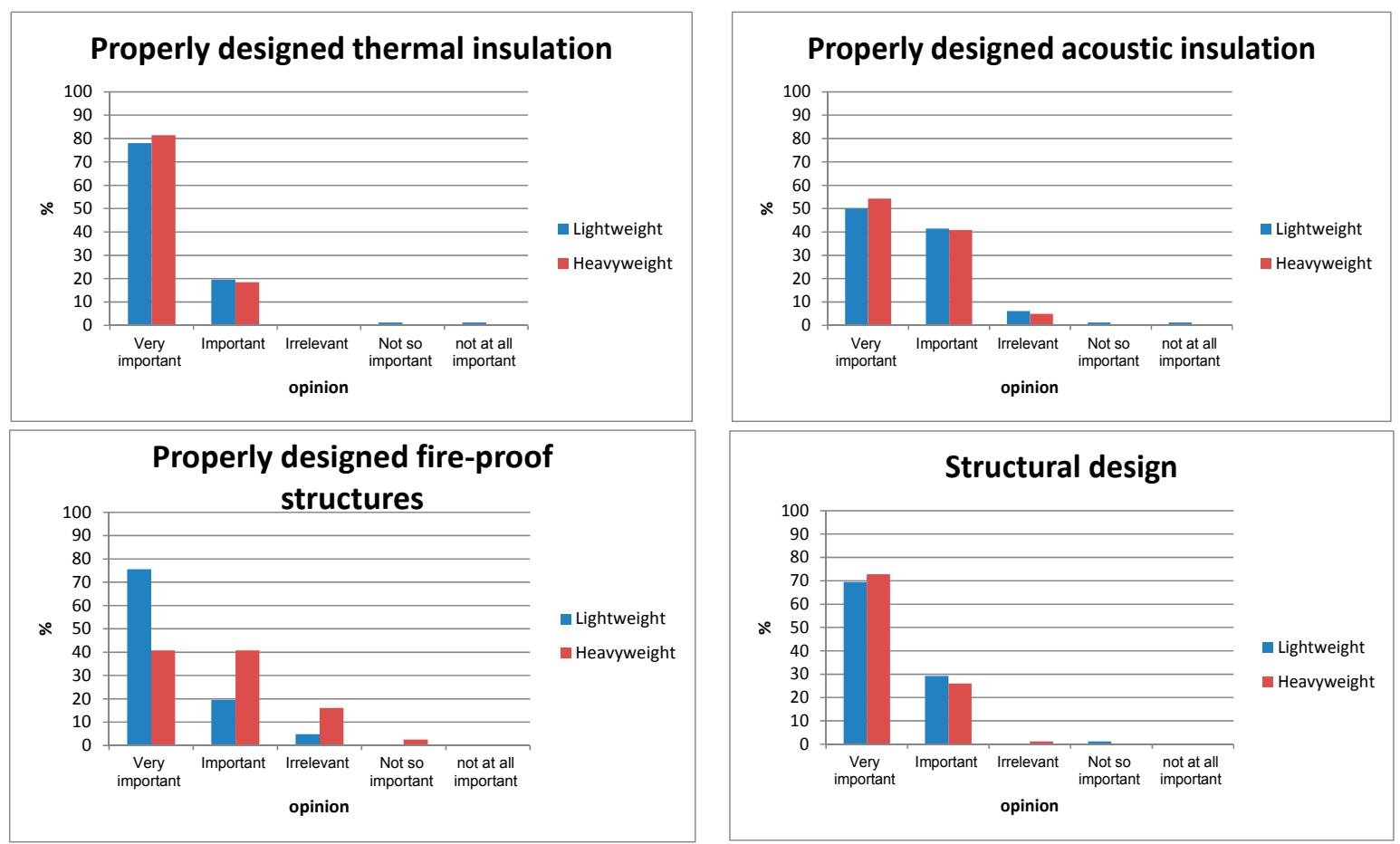

Figure 10. Italian results—opinion on design importance.

In Figure 11, the opinion on a turnkey delivery service is reported. It is clear that it is more requested for lightweight construction than for the other ones, but this point is not of major interest, though, people like and want to follow their houses' construction systematically. 


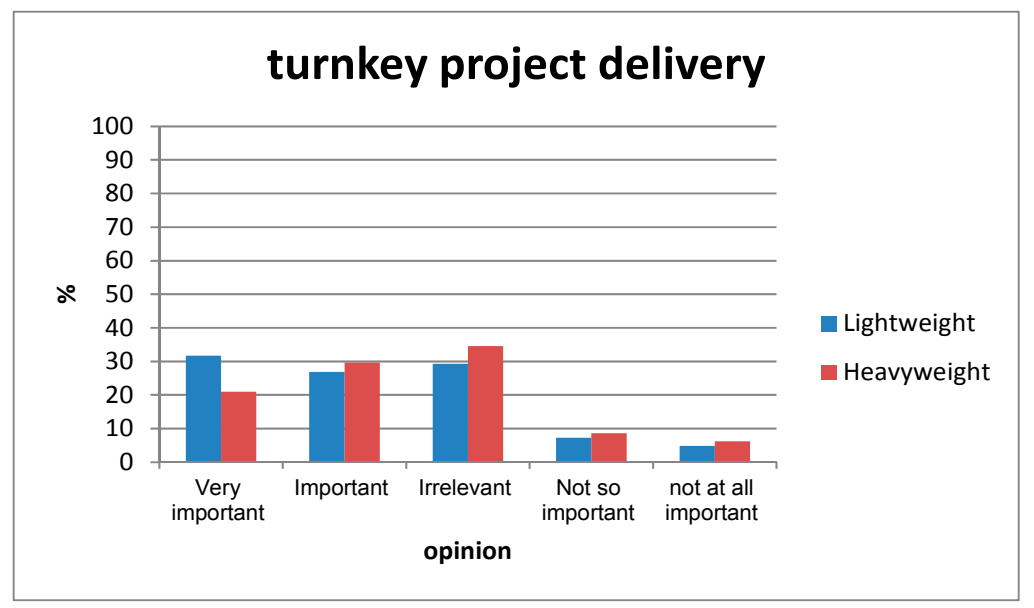

Figure 11. Italian results—opinion on turnkey project delivery.

\subsection{International Percentage Results}

The International responses are described hereafter. In Figure 12, it is highlighted how people have two different attitudes for thermal and acoustic topics: for the first one, it is a common view that it is of paramount importance for both typologies, whereas for acoustic insulation half of results show that this is very important aspect. Conversely, in both cases, the assessment provides almost the same percentage outcomes. Comparable behaviours and results are found for Italian estimations (Figures 3 and 4).

In Figure 13, the materials effects opinions are described. A common trend could not be found, because the materials of the heavyweight constructions are supposed to produce comfortable indoor environment and to effect the thermal protection. In Figure 14, the results regarding the impact of conditioning technologies are depicted. Trends comparable to Italian ones are evidenced, excluding for those connected to radiators (lightweight) and warm air (both). The need of windows opening presents similar significance. In Figure 15, the impact of proper design is described.
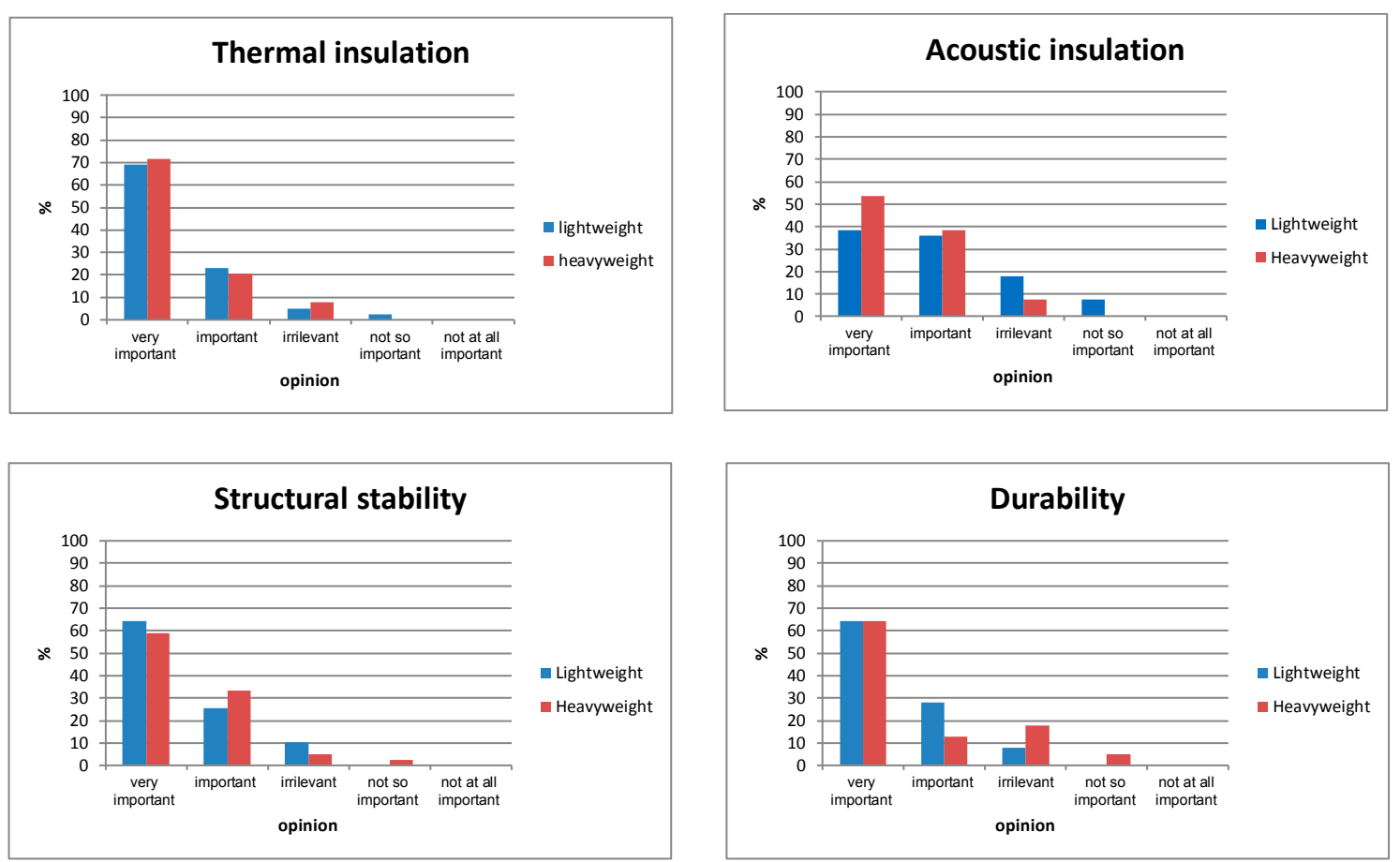

Figure 12. Cont. 

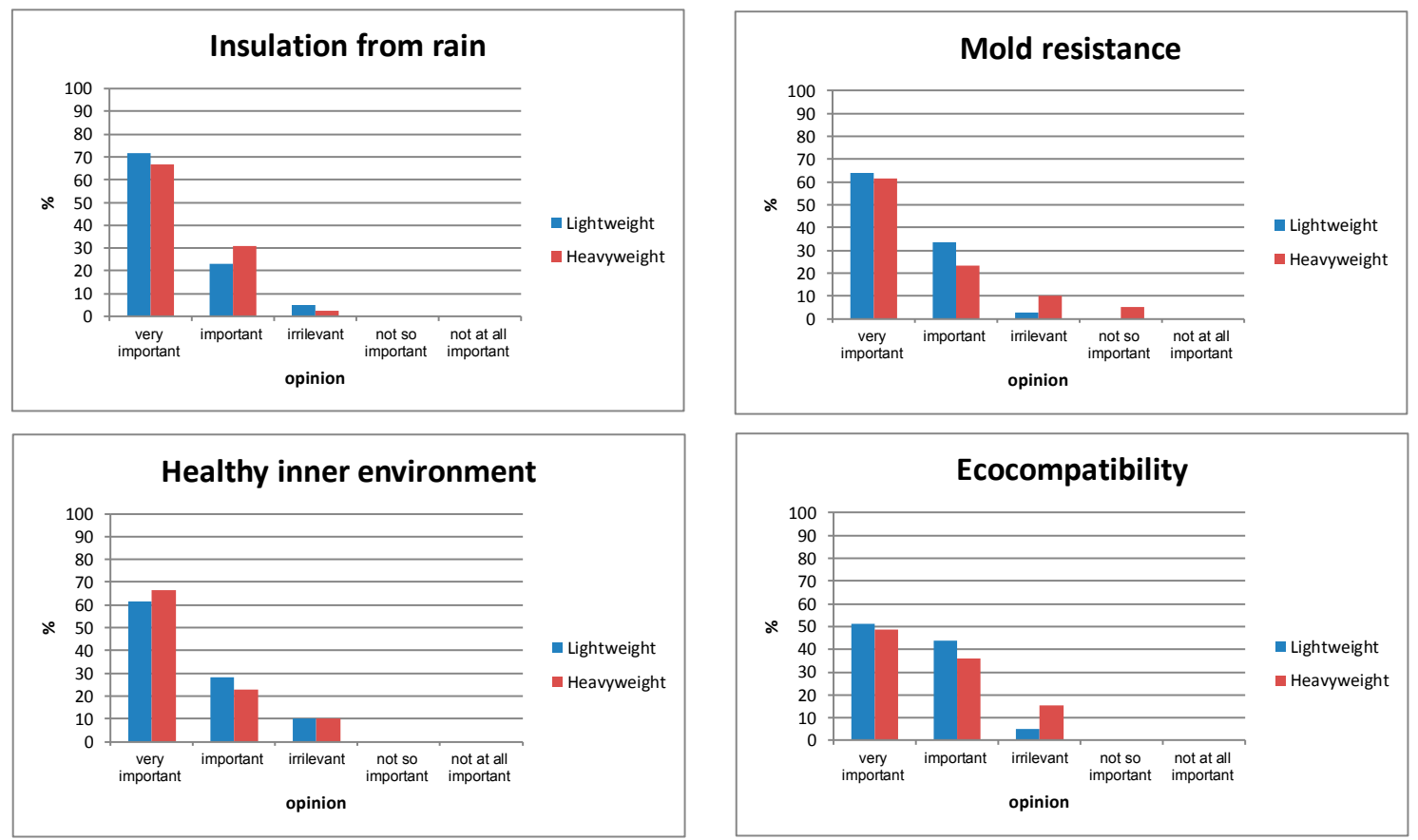

Figure 12. International results. General topic.

Comparable trends with Italian responses could be confirmed. A higher reputation is accredited to the thermal and acoustic insulation of heavyweight buildings demonstrating that people do not appreciate them as timber ones. On the other hand, for proper fire-resistance design the reverse situation could be reported.
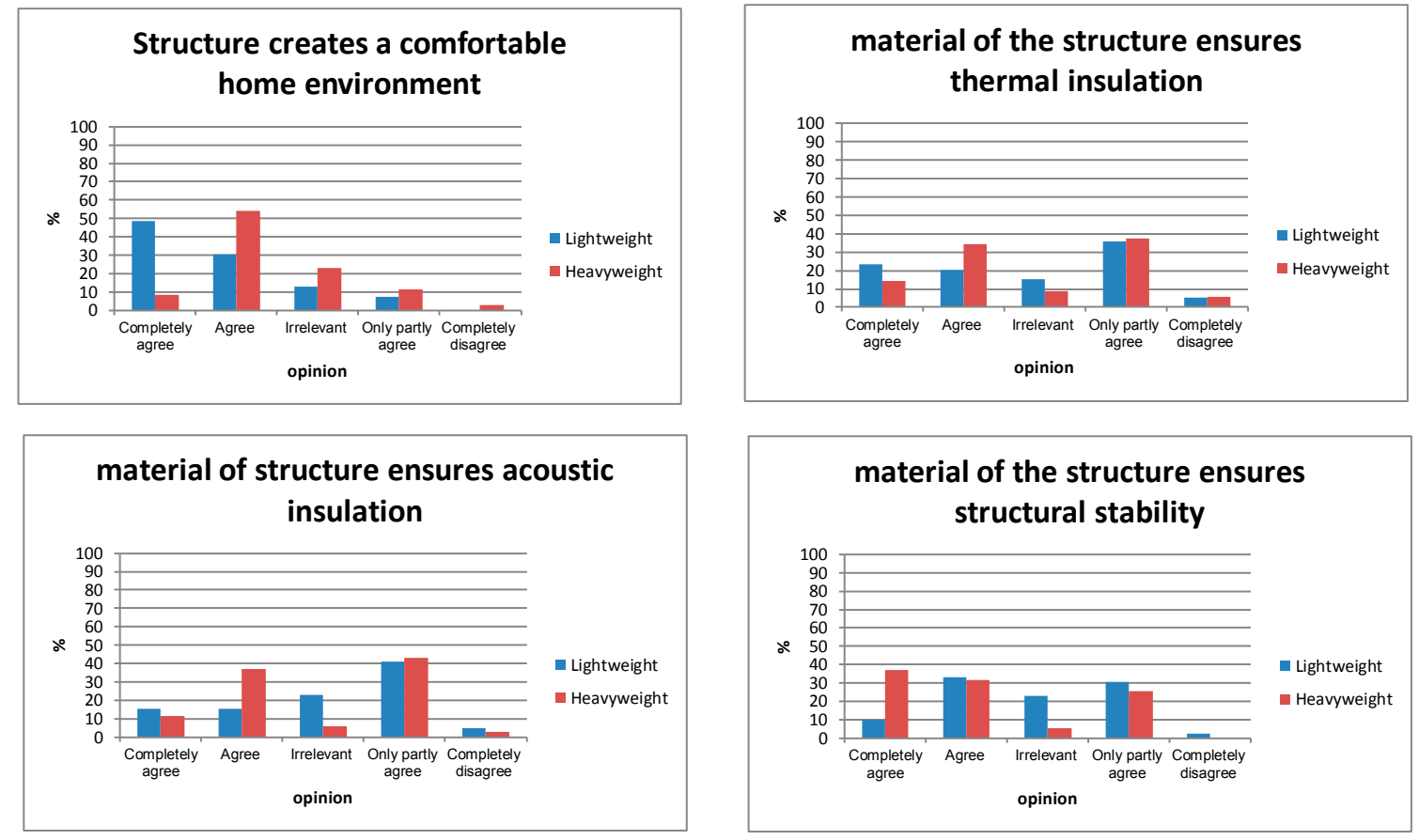

Figure 13. International results. Influence of materials. 

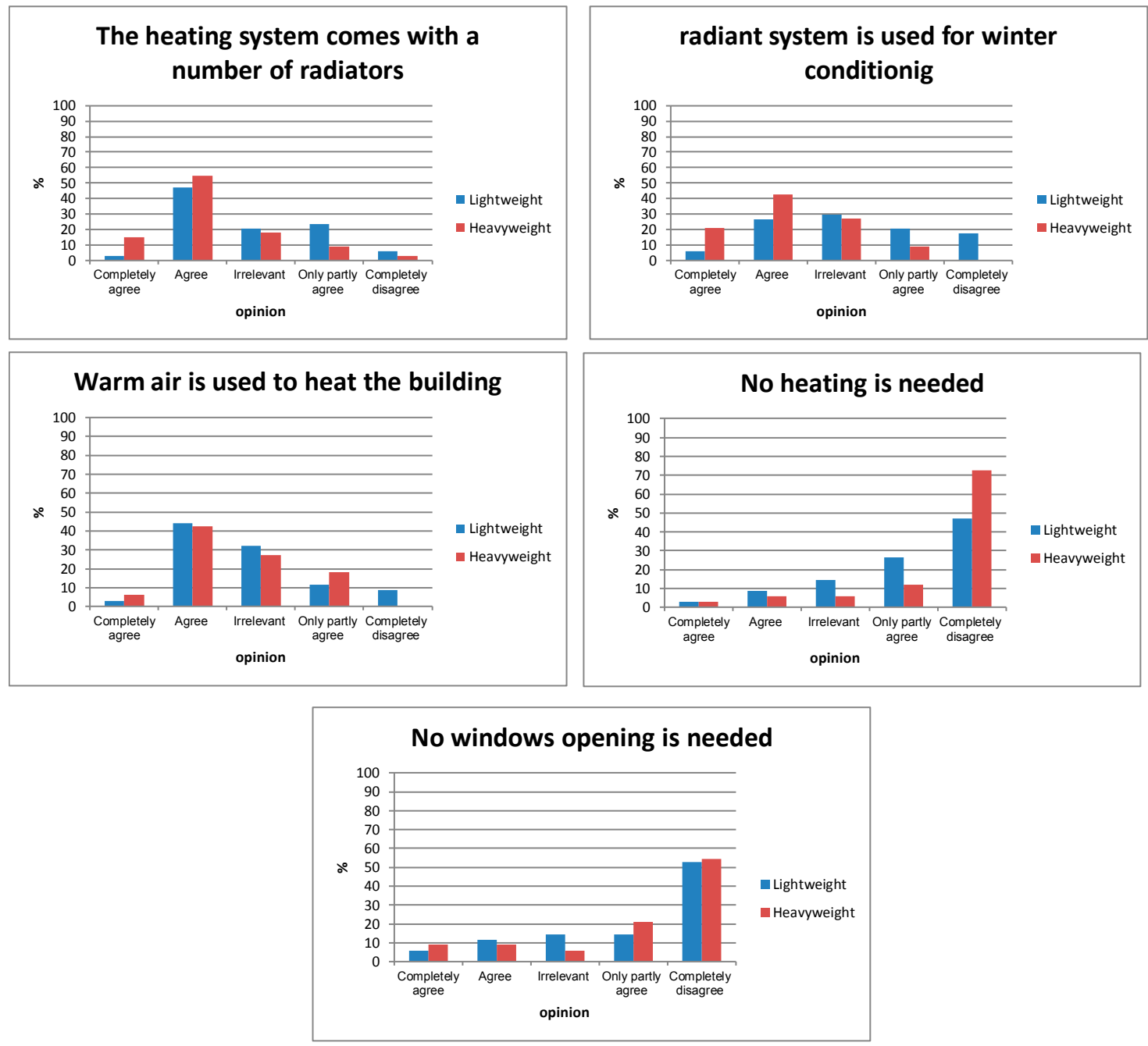

Figure 14. International results. Influence of conditioning system.
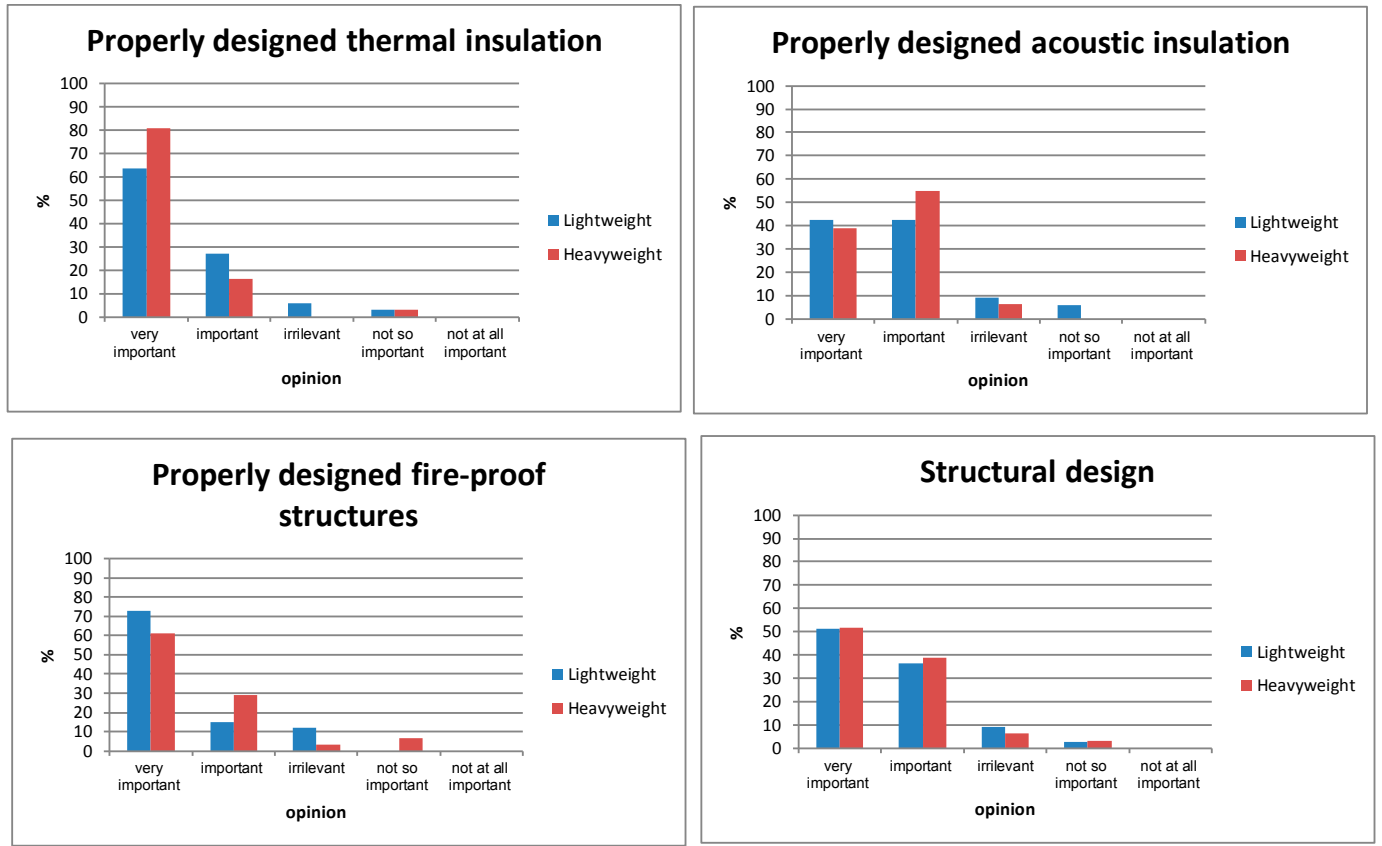

Figure 15. Cont. 


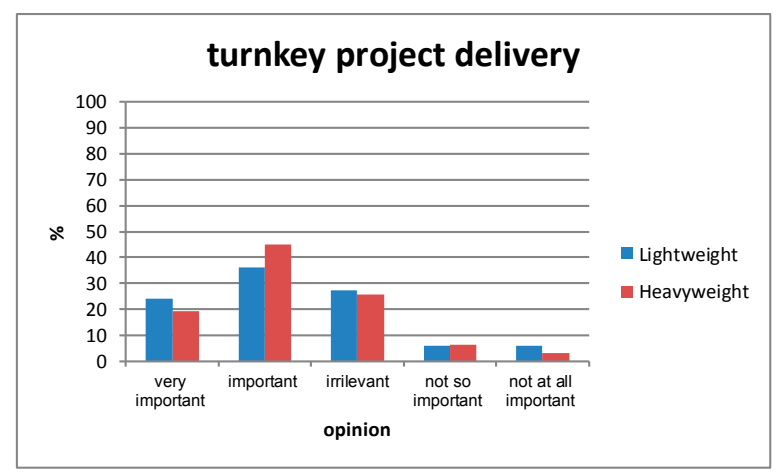

Figure 15. International results. Influence of proper design.

\subsection{Inferential Analysis for the Italian Group}

In this section the results of the inferential analysis are reported and plotted in terms of Mann-Whitney U Test, average and Spearman's rank correlation coefficient. Other results (min.-max.; Median, Standard Deviation and Variance) are reported in Appendices A and B. In Table 4 the comparison between indexes of timber and conventional buildings is reported, while in Figure 16 the averaged mean values are compared.

Table 4. Comparison of indexes between timber and conventional buildings.

\begin{tabular}{|c|c|c|c|c|c|}
\hline Index & Question & $\mathbf{U}$ & z-Score & $p$ & $\begin{array}{l}\text { Significant } \\
\text { at } p<0.05\end{array}$ \\
\hline \multirow{8}{*}{ General topics } & Thermal insulation & 4563.5 & -0.34798 & 0.36317 & No \\
\hline & Acoustic insulation & 4604 & 0.24435 & 0.40517 & No \\
\hline & Structural stability & 4244 & -1.16546 & 0.121 & No \\
\hline & Durability & 4608 & -0.23412 & 0.40905 & No \\
\hline & Insulation from rain & 4107.5 & -1.51472 & 0.06552 & No \\
\hline & Resistance to mold & 4605 & -0.24179 & 0.40517 & No \\
\hline & Healthy indoor environment & 4698 & -0.00384 & 0.5 & No \\
\hline & Sustainability & 4172 & -1.34968 & 0.08851 & No \\
\hline \multirow{4}{*}{$\begin{array}{c}\text { Structural } \\
\text { materials } \\
\text { impact }\end{array}$} & $\begin{array}{l}\text { Wood (or bricks etc.) creates a comfortable } \\
\text { home environment }\end{array}$ & 1480 & 7.41632 & $<0.00001$ & Yes \\
\hline & $\begin{array}{l}\text { Wood (or bricks etc.) ensures } \\
\text { thermal insulation }\end{array}$ & 2241.5 & -5.25541 & $<0.00001$ & Yes \\
\hline & $\begin{array}{l}\text { Wood (or bricks etc.) ensures } \\
\text { acoustic insulation }\end{array}$ & 3341 & -2.13537 & 0.01618 & Yes \\
\hline & $\begin{array}{l}\text { Wood (or bricks etc.) ensures } \\
\text { structural stability }\end{array}$ & 3896.5 & 0.55903 & 0.28774 & No \\
\hline \multirow{5}{*}{$\begin{array}{l}\text { Conditioning } \\
\text { technologies }\end{array}$} & $\begin{array}{c}\text { The heating system comes with a number } \\
\text { of radiators }\end{array}$ & 1813 & 5.43763 & $<0.00001$ & Yes \\
\hline & Radiant heating is used (e.g., floor heating) & 3038.5 & 1.54976 & 0.06057 & No \\
\hline & Warm air is used to heat the building & 2973.5 & 1.75597 & 0.0392 & Yes \\
\hline & No heating is needed & 2715 & -2.57605 & 0.00494 & Yes \\
\hline & Windows need not be opened & 3155 & -1.18016 & 0.119 & No \\
\hline \multirow{5}{*}{$\begin{array}{l}\text { Design } \\
\text { properties }\end{array}$} & Properly designed thermal insulation & 3152 & 0.55927 & 0.28774 & No \\
\hline & Properly designed acoustic insulation & 3088.5 & 0.77003 & 0.22065 & No \\
\hline & Properly designed fire-proof structures & 2088.5 & -4.08912 & $<0.00001$ & Yes \\
\hline & Structural design & 3171 & 0.4962 & 0.30854 & No \\
\hline & Turnkey project delivery & 2943.5 & -1.2513 & 0.10565 & No \\
\hline
\end{tabular}



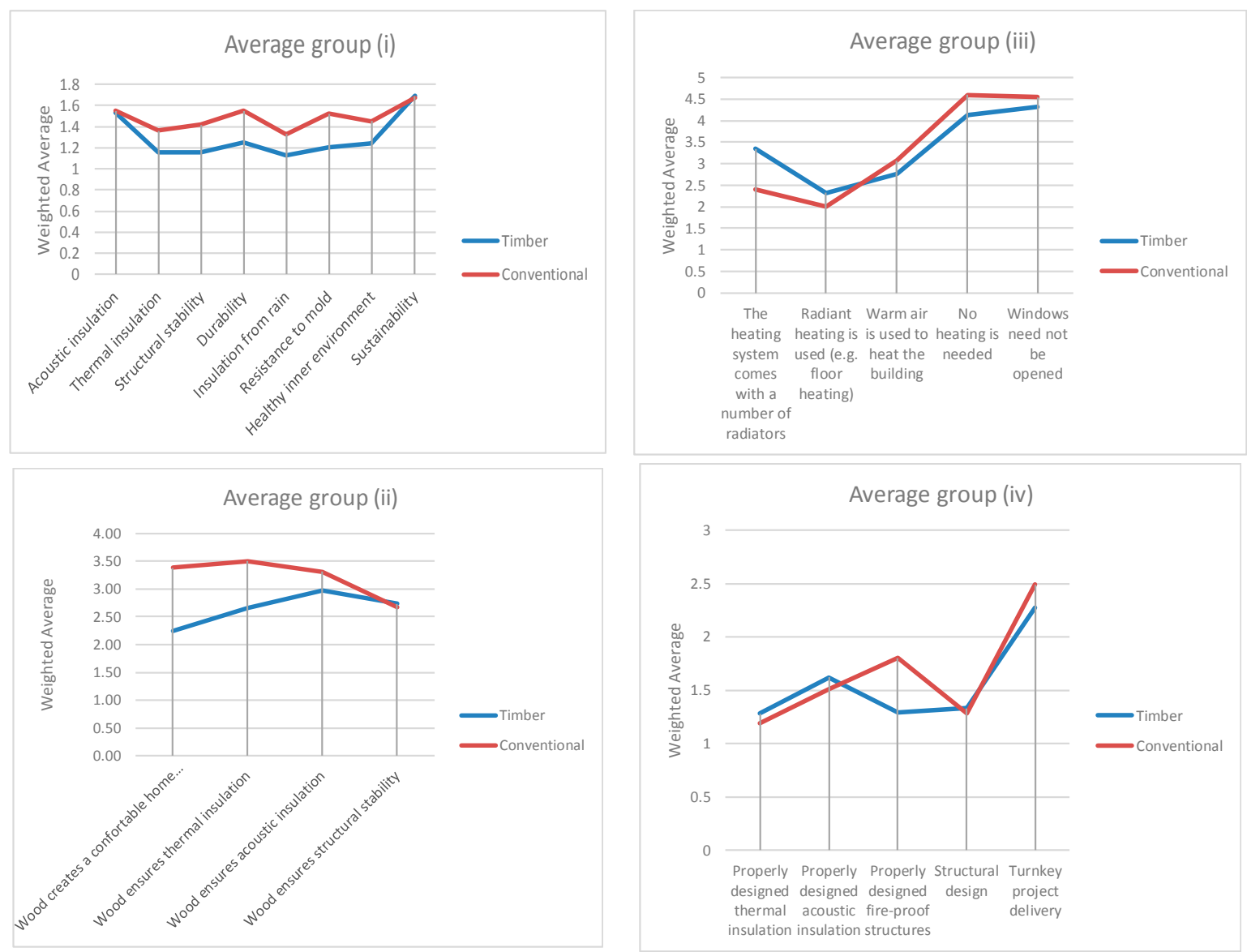

Figure 16. Italian results. Average values.

Table 5 illustrates the correlation between the thermal insulation index (group (i)) and thermal-correlated and acoustics-correlated indexes in groups (ii), (iii) and (iv): a) influence of the structure on home environment; $b$ ) influence of the structure on thermal insulation; $c$ ) influence of the structure on acoustic insulation; d) radiators; e) radiant systems; f) warm air; g) design of thermal insulation) h) design of acoustic insulation. On the other hand, in Table 6 the correlation between the acoustic insulation index (group (i)) and acoustics-correlated indexes in groups (ii) and (iv): c) influence of the structure on acoustic insulation; h) design of acoustic insulation.

Table 5. Italian results. Spearman's rank correlation coefficient between Group (i) "thermal insulation" and group (ii), (iii) and (iv) thermal-correlated and acoustics-correlated items.

\begin{tabular}{ccccc}
\hline \multirow{2}{*}{ Compared Item } & \multicolumn{2}{c}{ Timber } & \multicolumn{2}{c}{ Conventional } \\
\cline { 2 - 5 } & Spearman's $\rho$ & $p$-Value & Spearman's $\rho$ & $p$-Value \\
\hline a) & 0.491 & $2.1 \times 10^{-7}$ & 0.516 & $1.0 \times 10^{-7}$ \\
\hline b) & 0.419 & $1.4 \times 10^{-5}$ & 0.578 & $1.0 \times 10^{-9}$ \\
\hline c) & 0.439 & $4.7 \times 10^{-6}$ & 0.536 & $2.6 \times 10^{-8}$ \\
\hline d) & 0.36 & $2.3 \times 10^{-5}$ & 0.480 & $9.7 \times 10^{-7}$ \\
\hline e) & 0.435 & $6.1 \times 10^{-6}$ & 0.470 & $1.7 \times 10^{-6}$ \\
\hline f) & 0.415 & $1.7 \times 10^{-5}$ & 0.454 & $4.3 \times 10^{-6}$ \\
\hline g) & 0.530 & $1.3 \times 10^{-8}$ & 0.598 & $1.9 \times 10^{-10}$ \\
\hline h) & 0.464 & $1.1 \times 10^{-6}$ & 0.507 & $1.8 \times 10^{-7}$ \\
\hline
\end{tabular}


Table 6. Italian results. Spearman's rank correlation coefficient between Group (i) "acoustic insulation" and group (ii) and (iv) acoustics-correlated items.

\begin{tabular}{ccccc}
\hline \multirow{2}{*}{ Compared Item } & \multicolumn{2}{c}{ Timber } & \multicolumn{2}{c}{ Conventional } \\
\cline { 2 - 5 } & Spearman's $\rho$ & $p$-Value & Spearman's $\boldsymbol{\rho}$ & $\boldsymbol{p}$-Value \\
\hline $\mathrm{c})$ & 0.824 & $6.4 \times 10^{-26}$ & 0.789 & $3.9 \times 10^{-20}$ \\
\hline $\mathrm{h})$ & 0.790 & $1.6 \times 10^{-22}$ & 0.843 & $1.9 \times 10^{-26}$ \\
\hline
\end{tabular}

\subsection{International Inference Analyses Results}

In this section the inference analyses results are reported and plotted in terms of Mann-Whitney U Test, average and Spearman's rank correlation coefficient. Other results (min.-max.; Median, Standard Deviation and Variance) are reported in Annex B. In Table 7, the comparison between indexes of timber and conventional buildings is reported while in Figure 17 the averaged mean values are compared.

Table 7. Comparison of indexes between timber and conventional buildings.

\begin{tabular}{|c|c|c|c|c|c|}
\hline Index & Question & $\mathbf{U}$ & z-score & $p$ & $\begin{array}{l}\text { Significant } \\
\text { at } p<0.05\end{array}$ \\
\hline \multirow{8}{*}{ General topics } & Thermal insulation & 755 & -0.04997 & 0.48006 & No \\
\hline & Acoustic insulation & 585 & 1.74884 & 0.04006 & Yes \\
\hline & Structural stability & 730.5 & -0.2948 & 0.38591 & No \\
\hline & Durability & 715.5 & -0.44471 & 0.32997 & No \\
\hline & Insulation from rain & 753 & -0.06995 & 0.4721 & No \\
\hline & Resistance to mold & 705.5 & -0.54464 & 0.2946 & No \\
\hline & Healthy indoor environment & 725.5 & 0.34477 & 0.36393 & No \\
\hline & Sustainability & 704 & 0.55963 & 0.28774 & No \\
\hline \multirow{4}{*}{$\begin{array}{l}\text { Structural } \\
\text { materials } \\
\text { impact }\end{array}$} & $\begin{array}{c}\text { Wood (or bricks etc.) creates a comfortable } \\
\text { home environment }\end{array}$ & 404 & -3.00439 & 0.00135 & Yes \\
\hline & $\begin{array}{l}\text { Wood (or bricks etc.) ensures } \\
\text { thermal insulation }\end{array}$ & 670.5 & -0.12451 & 0.45224 & No \\
\hline & $\begin{array}{l}\text { Wood (or bricks etc.) ensures } \\
\text { acoustic insulation }\end{array}$ & 611 & 0.76869 & 0.22065 & No \\
\hline & $\begin{array}{l}\text { Wood (or bricks etc.) ensures } \\
\text { structural stability }\end{array}$ & 367 & 3.41039 & 0.00032 & Yes \\
\hline \multirow{5}{*}{$\begin{array}{l}\text { Conditioning } \\
\text { technologies }\end{array}$} & $\begin{array}{l}\text { The heating system comes with a number } \\
\text { of radiators }\end{array}$ & 406.5 & 1.93135 & 0.0268 & Yes \\
\hline & Radiant heating is used (e.g., floor heating) & 349 & 2.65247 & 0.00402 & Yes \\
\hline & Warm air is used to heat the building & 552.5 & 0.10033 & 0.46017 & No \\
\hline & No heating is needed & 425.5 & -1.69306 & 0.04551 & Yes \\
\hline & Windows need not be opened & 545.5 & -0.18812 & 0.42465 & No \\
\hline \multirow{5}{*}{$\begin{array}{l}\text { Design } \\
\text { properties }\end{array}$} & Properly designed thermal insulation & 391 & 1.61205 & 0.0537 & No \\
\hline & Properly designed acoustic insulation & 500 & 0.14777 & 0.44038 & No \\
\hline & Properly designed fire-proof structures & 459.5 & -0.69184 & 0.2451 & No \\
\hline & Structural design & 510 & -0.01343 & 0.49601 & No \\
\hline & Turnkey project delivery & 508 & 0.0403 & 0.48405 & No \\
\hline
\end{tabular}



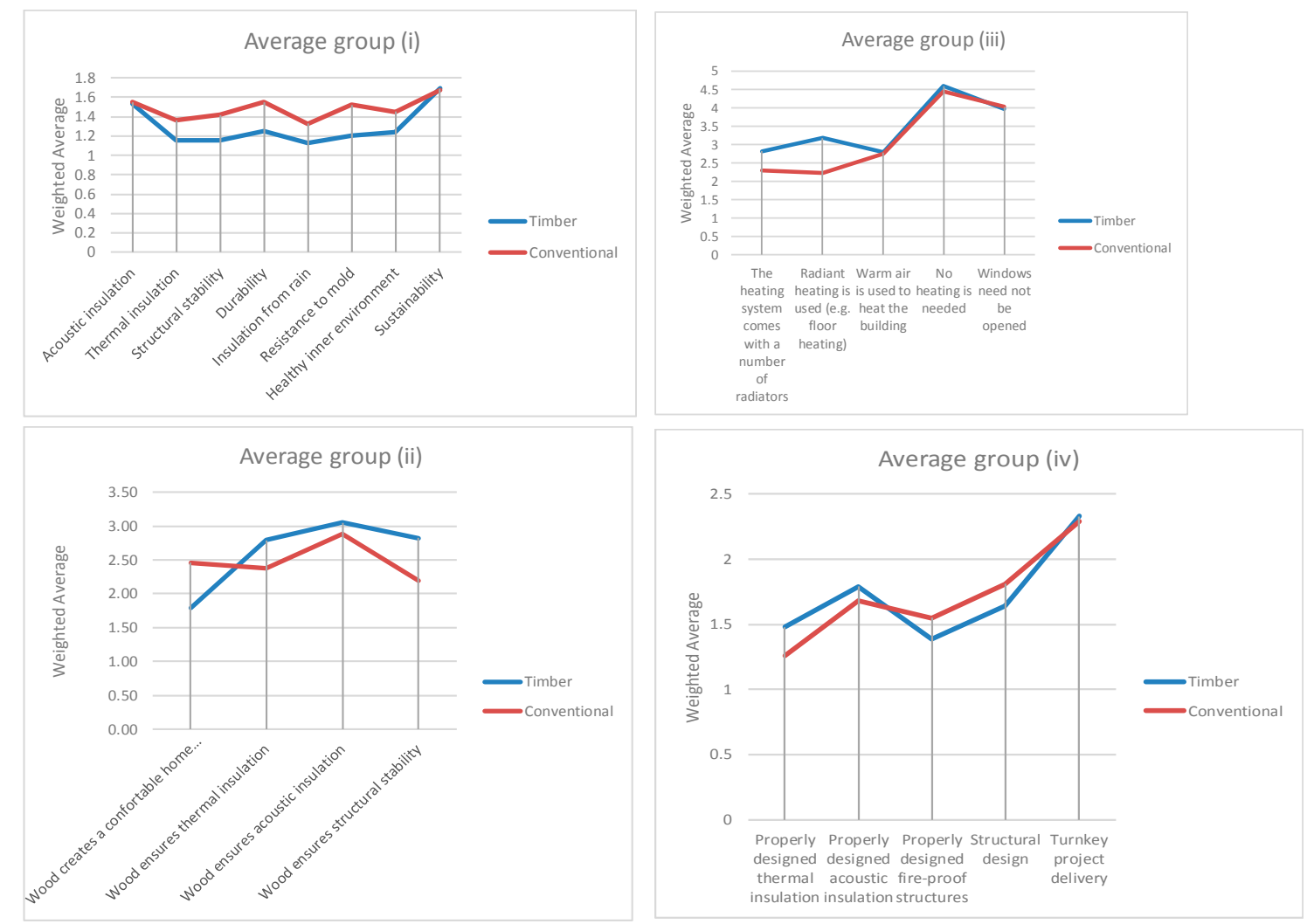

Figure 17. International results. Average values.

Table 8 illustrates the correlation between the thermal insulation index (group (i)) and thermal-correlated and acoustics-correlated indexes in groups (ii), (iii) and (iv): a) influence of the structure on home environment; b) influence of the structure on thermal insulation; c) influence of the structure on acoustic insulation; d) radiators; e) radiant systems; f) warm air; g) design of thermal insulation) h) design of acoustic insulation. On the other hand, in Table 9 the correlation between the acoustic insulation index (group (i)) and acoustics-correlated indexes in groups (ii) and (iv): c) influence of the structure on acoustic insulation; h) design of acoustic insulation

Table 8. International results. Spearman's rank correlation coefficient between Group (i) “thermal insulation" and group (ii), (iii) and (iv) thermal-correlated and acoustics-correlated items.

\begin{tabular}{ccccc}
\hline \multirow{2}{*}{ Compared Item } & \multicolumn{2}{c}{ Timber } & \multicolumn{2}{c}{ Conventional } \\
\cline { 2 - 5 } & Spearman's $\rho$ & $p$-Value & Spearman's $\rho$ & $p$-Value \\
\hline a) & 0.715 & $3.0 \times 10^{-7}$ & 0.716 & $3.0 \times 10^{-7}$ \\
\hline b) & 0.653 & $6.6 \times 10^{-6}$ & 0.595 & $6.5 \times 10^{-5}$ \\
\hline c) & 0.614 & $3.2 \times 10^{-5}$ & 0.539 & $4.0 \times 10^{-5}$ \\
\hline d) & 0.680 & $1.9 \times 10^{-6}$ & 0.658 & $5.2 \times 10^{-6}$ \\
\hline e) & 0.685 & $1.5 \times 10^{-6}$ & 0.622 & $2.3 \times 10^{-5}$ \\
\hline f) & 0.747 & $4.6 \times 10^{-8}$ & 0.614 & $3.3 \times 10^{-5}$ \\
\hline g) & 0.528 & $5.5 \times 10^{-5}$ & 0.793 & $1.7 \times 10^{-9}$ \\
\hline h) & 0.703 & $5.9 \times 10^{-7}$ & 0.609 & $3.8 \times 10^{-5}$ \\
\hline
\end{tabular}


Table 9. International results. Spearman's rank correlation coefficient between group (i) "acoustic insulation" and group (ii) and (iv) acoustics-correlated items.

\begin{tabular}{ccccc}
\hline \multirow{2}{*}{ Compared Item } & \multicolumn{2}{c}{ Timber } & \multicolumn{2}{c}{ Conventional } \\
\cline { 2 - 5 } & Spearman's $\rho$ & $p$-Value & Spearman's $\boldsymbol{\rho}$ & $\boldsymbol{p}$-Value \\
\hline $\mathrm{c})$ & 0.881 & $1.3 \times 10^{-13}$ & 0.830 & $6.4 \times 10^{-11}$ \\
\hline $\mathrm{h})$ & 0.969 & $5.5 \times 10^{-24}$ & 0.604 & $4.7 \times 10^{-5}$ \\
\hline
\end{tabular}

\section{Discussion}

An international web-based survey was realized and used to understand what non-expert people expect both from conventional heavyweight and from lightweight timber buildings. The results confirm that timber buildings are perceived as possessing higher energy performance and fire hazard, while for conventional heavyweight ones no particular bias was found. Collecting feedbacks from non-expert involves a range of techniques, used as drawn from social science research [65-72]. Questionnaires, diaries and interviews are managed in order to optimize data collection procedure.

It could be understood that peoples' expectation about thermal insulation is highly important for lightweight buildings. Meanwhile they also expect high indoor comfort performance, which they may take for granted. The respondents do not live in lightweight buildings and thus it should be assumed that the respondents live in heavyweight buildings. For these reasons, their thermal and acoustic performance perception of this type of construction is affected by the quality of the building where they live. Conventional heavyweight materials seem not to provide comfort and conversely wood is perceived as leading to indoor comfort.

Non-experts trust timber buildings as they are perceived as very good constructions to live in and where every conventional issue is solved. On the other hand, there is no deep distrust of conventional building, even if their rates are poorer and the attention on the design step is higher. These findings validates previous literature which sustains that indoor environments are positively evaluated by green building occupants [53] and that occupants' behaviours are influenced in green buildings [52]. Besides, indoor satisfaction appears to be enhanced into green environments occupant's opinion [67].

Timber constructions are felt like newer and more reliable as demonstrated by the results, related to conditioning technologies: radiators (old) are only related to conventional buildings, while radiant and air systems are correlated to lightweight ones. Even on the extreme question about the possibility to have no heating system at all, more than $50 \%$ of the people think that for the lightweight buildings this chance is realizable.

From the geographical point of view, general topics obtained almost the same results or trends among Italian and international respondents. Differences could be found in the influence of materials, because in the international ones it is evident how the heavyweight buildings are believed to provide better performance provided by materials of the structures. This suggest that in Italy there is a better consciousness of conventional buildings features; this is confirmed by the large number of this kind of edifices present in the country, implying a large number of people living inside them.

Other differences are highlighted on the use of radiators as heating system. Italian people do associate them to old style heavyweight buildings, but international results indicate that they are contemplated within timber buildings too. This is a big difference, because for high energy saving constructions, radiators are not eligible for heating technology. This fact highlights how Italian people's stereotype of timber buildings is the high efficiency one. Furthermore, the dedicated design for thermal and acoustic insulation is perceived to be very important for Italian response for both technologies, while for international ones the heavyweight show a higher importance.

\section{Statistic Evaluations}

In this research, an association of Likert-type 5-point scale was used. This method was utilized in order to assess people's expectations on timber and conventional buildings supported by statistical 
analysis. It is notable that Cronbach's alphas value was $>0.9$ proving a high consistency of the survey, based on item variances [68]. The survey consistency indicates how robust, stable, reliable or precise the tool is [69] and this procedure highlights how the methodology used in this study satisfies this requirement. People's personal data were collected, but they were used only to characterize samples and they were not been considered in the statistical analysis.

If subjective considerations are converted to numerical values, then statistical analysis could be performed. As reported in Tables 1-3 the range 1-5 was used to achieve this transformation. In annexes $\mathrm{A}$ and $\mathrm{B}$ the statistical parameters for every item are reported.

In this section, the average values as well as the Mann-Whitney $U$ test results will be discussed, because they report the importance of the subjective evaluation and its orientation on a single item. Finally, Spearman's test was performed.

For Italian results, the best-rated and worst-rated items are reported in Table 10, highlighting that for timber buildings in all groups, thermal-related items are always the best-rated ones, while acoustics appears as the worst-rated item twice. For conventional constructions, thermal items as well as structural ones are the best rated, while for the worst one no particular leading topic is identified.

Table 10. Best and worst rated items-Italian results.

\begin{tabular}{|c|c|c|c|c|}
\hline Group Number & \multicolumn{2}{|c|}{ Timber } & \multicolumn{2}{|c|}{ Conventional } \\
\hline Group (i) & $\begin{array}{l}\text { Thermal and rain } \\
\text { insulation }\end{array}$ & $\begin{array}{l}\text { Acoustic insulation } \\
\text { Sustainability }\end{array}$ & $\begin{array}{c}\text { Thermal and rain } \\
\text { insulation }\end{array}$ & $\begin{array}{l}\text { Acoustic insulation } \\
\text { Sustainability }\end{array}$ \\
\hline Group (ii) & $\begin{array}{l}\text { Wood creates a } \\
\text { comfortable home } \\
\text { environment }\end{array}$ & $\begin{array}{l}\text { Wood ensure } \\
\text { acoustic insulation }\end{array}$ & $\begin{array}{l}\text { Bricks, etc. ensure } \\
\text { structural stability }\end{array}$ & $\begin{array}{c}\text { Bricks, etc. creates } \\
\text { a comfortable } \\
\text { home environment }\end{array}$ \\
\hline Group (iii) & Radiant heating is used & $\begin{array}{l}\text { Windows need not } \\
\text { to be opened }\end{array}$ & Radiant heating is used & $\begin{array}{l}\text { Windows need not } \\
\text { to be opened }\end{array}$ \\
\hline Group (iv) & $\begin{array}{c}\text { Properly designed } \\
\text { thermal and fire-proof } \\
\text { insulation }\end{array}$ & $\begin{array}{c}\text { Turnkey project } \\
\text { delivery }\end{array}$ & $\begin{array}{l}\text { Properly designed } \\
\text { thermal insulation and } \\
\text { structural stability }\end{array}$ & $\begin{array}{c}\text { Turnkey project } \\
\text { delivery }\end{array}$ \\
\hline
\end{tabular}

Analysing only the best and worst rated items and considering separately timber and conventional technologies, it could be understood that for groups (i) and (iii) small differences could be perceived, highlighting that expectations are similar. In group (ii), timber is believed to provide a better indoor comfort, while it could not ensure acoustic insulation. The results of these items report a confusing expectation on wood performances. On the other hand, conventional buildings expectations are based on structural stability and no trust is demonstrated on indoor comfort using heavyweight materials. Group (iv) shows similar trends except for fire-proof design which is surely associated to timber buildings.

For International results, the best-rated and worst-rated items are reported in Table 11. For groups (i), (ii) and (iii) thermal-related items are always the best-rated ones, while acoustic appear as worst-rated item twice. For conventional constructions, thermal items as well as structural ones are the best rated while for the worst one no particular leading topic is identified.

Analysing only the best and worst rated items and comparing timber and conventional technologies, it could be highlighted that for best-items there is no common trend except for group (i), while for the worst-rated items there is a similar tendency, excluding group (i). It can be concluded that there are common expectation on worst items comparing the two technologies. In group (ii), timber is believed to provide a good indoor comfort, while it could not ensure acoustic insulation. The results of these items report a confusing expectation on wood performances. On the other hand, conventional buildings expectations are based on structural stability and there is a real distrust on acoustic heavyweight materials performances. 
Table 11. Best and worst rated items-International results.

\begin{tabular}{|c|c|c|c|c|}
\hline \multirow[t]{2}{*}{ Group Number } & \multicolumn{2}{|c|}{ Timber } & \multicolumn{2}{|c|}{ Conventional } \\
\hline & Best-Rated & Worst-Rated & Best-Rated & Worst-Rated \\
\hline Group (i) & $\begin{array}{l}\text { Thermal and rain } \\
\text { insulation }\end{array}$ & Acoustic insulation & $\begin{array}{l}\text { Thermal and rain } \\
\text { insulation }\end{array}$ & $\begin{array}{l}\text { Durability and } \\
\text { resistance to mold }\end{array}$ \\
\hline Group (ii) & $\begin{array}{l}\text { Wood creates a } \\
\text { comfortable home } \\
\text { environment }\end{array}$ & $\begin{array}{c}\text { Wood ensure } \\
\text { acoustic insulation }\end{array}$ & $\begin{array}{l}\text { Bricks, etc. ensure } \\
\text { structural stability }\end{array}$ & $\begin{array}{l}\text { Bricks, etc. ensure } \\
\text { acoustic insulation }\end{array}$ \\
\hline Group (iii) & $\begin{array}{l}\text { Warm air is used to heat } \\
\text { the building }\end{array}$ & $\begin{array}{l}\text { No heating is } \\
\text { needed }\end{array}$ & $\begin{array}{l}\text { Radiators and radiant } \\
\text { heating are used }\end{array}$ & $\begin{array}{l}\text { No heating is } \\
\text { needed }\end{array}$ \\
\hline Group (iv) & $\begin{array}{l}\text { Properly designed } \\
\text { fire-proof structures }\end{array}$ & $\begin{array}{l}\text { Turnkey project } \\
\text { delivery }\end{array}$ & $\begin{array}{l}\text { Properly designed } \\
\text { thermal insulation }\end{array}$ & $\begin{array}{l}\text { Turnkey project } \\
\text { delivery }\end{array}$ \\
\hline
\end{tabular}

Analysing only the best and worst rated items and comparing timber and conventional technologies, it could be understood that for group (i) the best-rated items are similar and (iii) small differences could be perceived, highlighting that expectations are similar. In group (ii), timber is believed to provide a good indoor comfort, while it could not ensure acoustic insulation. The results of these items report a confusing expectation on wood performances. On the other hand, conventional buildings expectations are found on structural stability and no trust is demonstrated on indoor comfort using heavyweight materials. Group (iv) demonstrate rather the same trends including fire-proof design which is surely associated with timber buildings.

Mann-Whitney $U$ test is a non-parametric test that is used to compare two samples to test while they are statistically equivalent or not. Mann-Whitney $U$ test is used for every field and it does not compare mean but median values of two samples. Thus, it is much more robust against outliers and heavy tail distributions. For the Italian results, this test highlighted that only eight items are statistically significant (with 5\% significance level) and have sensible differences in median values. It could be outlined that the significant parameters are contained in groups (ii), (iii) and (iv). On the other hand, for the International results six items were identified as significant, contained in groups (i), group (ii), and group (iii). These results are in perfect agreement with the average ones, presented in the previous section. Furthermore the two combined analysis strengthen the verification of presented hypothesis, demonstrating how there are preconceptions well-correlated to timber buildings rather than conventional ones.

Up to this point, the various items included in the questionnaires have been analysed in order to understand if there are statistically significant differences in non-expert people's expectations between the two construction technologies. From this point, only common items will be taken into account. This allows the reduction of the analysis to few relevant factors as reported in Table 12. The item "radiant heating is used (e.g., floor heating)", was considered as well, because in Table 4 the $p$ values is slightly over 0.05 and from Figure 15 it could be inferred that a sensible difference is present.

Table 12. Important selected items.

\begin{tabular}{c}
\hline Common Items Selected from Mann-Whitney U Test \\
\hline Wood (or bricks etc.) creates a comfortable home environment \\
\hline The heating system comes with a number of radiators \\
Radiant heating is used (e.g., floor heating) \\
No heating is needed
\end{tabular}

From the two main analyses (average and Mann-Whitney $U$ test), it could then be highlighted that people expectations on timber buildings differ from those on conventional ones only about indoor comfort and how this issue could be extended to the conditioning technologies. This is a very important result because it demonstrates that people do present expectations on timber buildings and this will 
influence their behaviour once they become sustainable green buildings inhabitants. These results confirm previous research on the determination on the influence of non-measurable and non-physical parameters on inhabitants [48] or users [70,71].

A clear correlation was found between thermal insulation (group (i)) item and energy-related items in groups (ii), (iii) and (iv), through Spearman test, as reported in Tables 5 and 8 . This analysis shows that thermal aspects and structural materials impacts, conditioning technologies and design properties are positively interrelated. It is very important to highlight that a correlation does not infer causality, but can be used in main explicative factors and is a useful tool in these studies [73].

Both for timber and for conventional buildings, Spearman's $\rho$ factors are similar in the two groups. These correlations reveal that all items are positively correlated with the thermal insulation aspect. However, there is a sensible statistical difference between the correlation of thermal insulation and the others items between the two groups (Italian and International). The correlation confirms the results of Mann-Whitney comparison that showed the best-ranked indexes proposing that the energy saving sensitization prevails over environmental aspects (e.g., sustainability).

Spearmen's $\rho$ factor analysis for acoustic aspects reports a higher than for thermal ones. This fact shows how acoustics issues are more focused than thermal ones and that non-expert people have a clear problem-solution idea and preconception on this topic rather than energy-saving ones. These findings corroborate previous literature ones [45], where the influence of people's opinion affected the final results.

Energy use in housing was linked largely to occupants' preferences and behaviour [74], which is determined by the number of people in the house, their age, occupancy patterns and numerous other individual preferences and stereotypes. The identification of these characteristics was demonstrated to be dependent on direct and indirect effect on indoor comfort perception $[75,76]$. The paramount importance of non-expert people expectation is thus highlighted in literature and in this research.

\section{Conclusions}

Non-expert peoples' performance expectations regarding sustainable timber and conventional heavyweight buildings were investigated using an international web-based questionnaire. The main aims were to understand if there were some stereotypes related to building physics parameters like thermal or acoustic insulation, indoor comfort and heating technologies.

The results highlight how for both construction typologies thermal insulation is almost the most important parameter both for final performance and for design priority. This aspect collected the same percentage of answer (very important) compared to the structural stability. Furthermore, the importance of the project gained from 10\% to 30\% more importance than the structural one.

The supporting structure is believed to create a comfortable home environment for timber building for Italian results, while for international ones the difference is not remarkable. Since by definition thermal comfort is a "state of mind", the subjective response assumes a paramount importance. More than $30 \%$ of the results indicate that non-expert people rely on structural timber for thermal insulation even if the same result (for international ones) could be related also for conventional materials (concrete, masonry etc.). This latter issue demonstrates some kind of confusion on the real roles of materials in constructions.

Heating systems topic provides almost the same results for the two types of construction technologies, except for radiators. Italian outcomes denote that this type of heating device is associated to conventional buildings rather than timber ones. Since radiators represent a conventional technology, it could be concluded that timber constructions are perceived like a new category of edifices, though requiring innovative systems.

As final conclusion, it could be stated that energy saving is one of the most rated parameter for sustainable timber buildings, while it is not so important for heavyweight ones.

As regards Italian people, a great deal of attention is devoted to thermal and acoustic insulation and this issue is more related to timber buildings rather than conventional ones. The latter issue is 
related to fire-proof dedicated design belonging to timber constructions. Conversely, according to international results, acoustic insulation issue is highlighted to be an important aspect for conventional buildings as well as structural stability.

It is interesting to note that the acoustic insulation is less important compared to thermal or rain ones, mold resistance, healthy environment durability and structural stability for both construction technologies. Acoustic design is not rated as important as the other ones and the influence of the structural material on the final insulation highlights for Italian results quite a "flat" results, demonstrating a confused idea on the issue. This outcome is confirmed by the international answers indicating that non-expert people's idea of sound insulation is not related to timber but is related to concrete or masonry. This could lead to two different alternative explanations:

(i) It is believed that wood constituting the structure could insulate from external and internal noise, by itself;

(ii) It is believed that timber buildings do not need acoustic design or acoustic insulation since they have some kind of standard sound insulation property due to the whole layering.

The combination of statistical analysis demonstrated how there are preconceptions well-correlated to timber buildings rather than conventional ones and thus the hypothesis that non-measurable psychological factors can have a non-negligible role in determining the final user perception, interaction, and adaptation to timber buildings has been verified. Future works will have to investigate on the possible presence of designers' stereotypes and the influence of dedicated education by mean of selected courses or seminars.

Author Contributions: M.C. developed the research. M.C. elaborated all data, methods analyses, statistics and comparisons. A.G. overviewed the research. M.C. wrote the paper.

Funding: This research has been funded by the project "Klimahouse and energy production" in the framework of the programmatic-financial agreement with the Autonomous Province of Bozen-Bolzano of Research Capacity Building. This work was also supported by the Open Access Publishing Fund of the Free University of Bozen-Bolzano.

Conflicts of Interest: The authors declare no conflict of interest.

\section{Appendix A -Statistical Parameters-Italian Results}

TIMBER

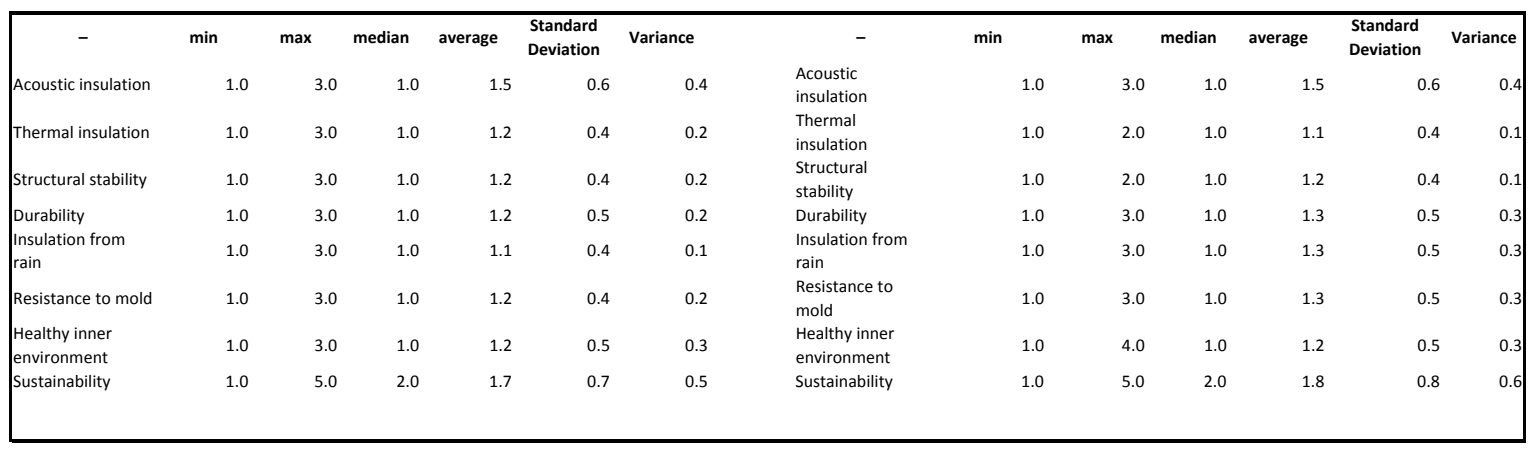




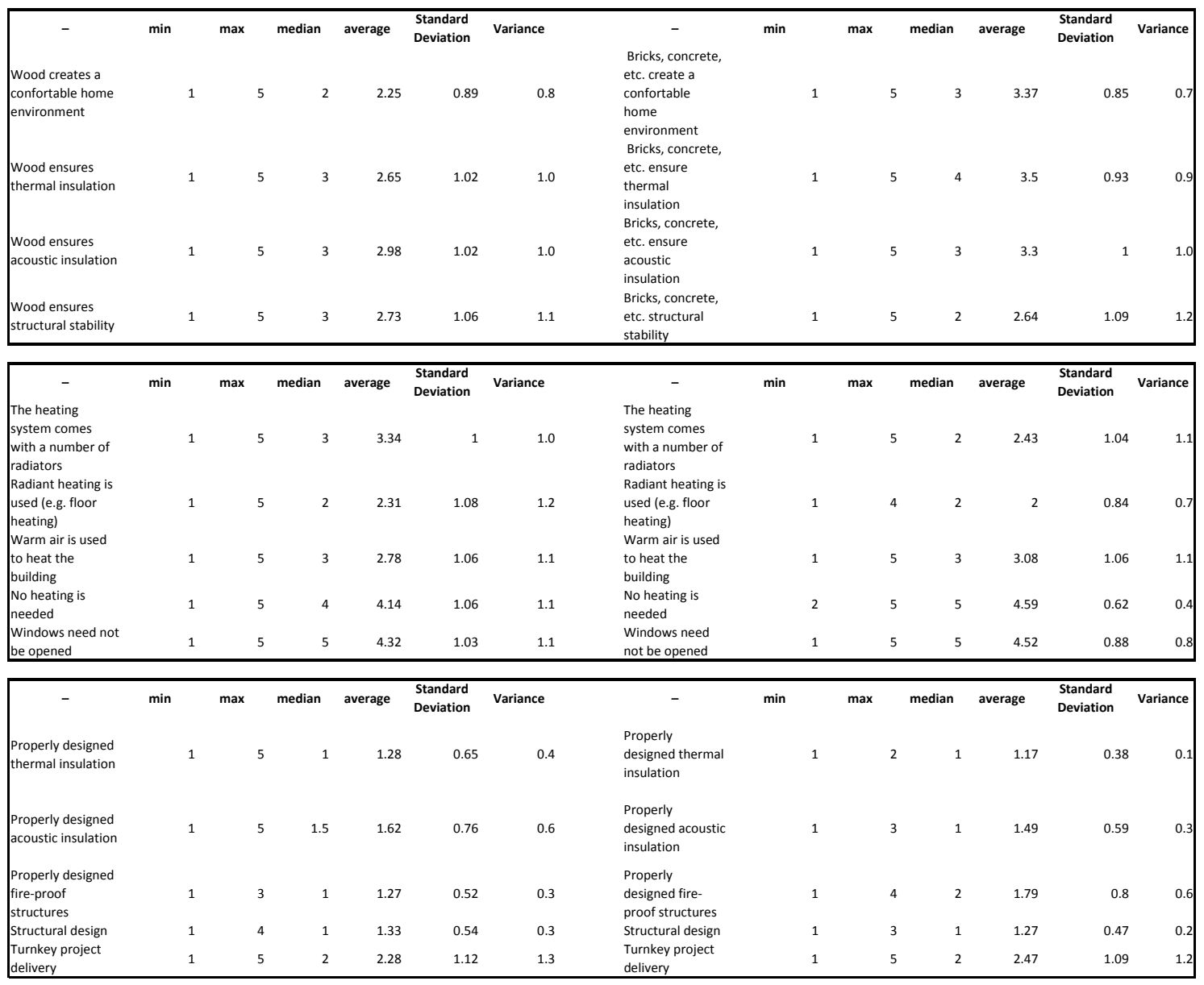

Appendix B -Statistical Parameters-International Results

TIMBER

CONVENTIONAL

\begin{tabular}{|c|c|c|c|c|c|c|c|c|c|c|c|c|c|}
\hline- & $\min$ & $\max$ & median & average & $\begin{array}{l}\text { Standard } \\
\text { Deviation }\end{array}$ & Variance & - & $\min$ & $\max$ & median & average & $\begin{array}{l}\text { Standard } \\
\text { Deviation }\end{array}$ & Variance \\
\hline Acoustic insulation & 1.0 & 4.0 & 2.0 & 2.0 & 0.9 & 0.9 & $\begin{array}{l}\text { Acoustic } \\
\text { insulation }\end{array}$ & 1.0 & 3.0 & 1.0 & 1.5 & 0.6 & 0.4 \\
\hline Thermal insulation & 1.0 & 4.0 & 1.0 & 1.4 & 0.7 & 0.5 & $\begin{array}{l}\text { Thermal } \\
\text { insulation }\end{array}$ & 1.0 & 3.0 & 1.0 & 1.4 & 0.6 & 0.4 \\
\hline Structural stability & 1.0 & 3.0 & 1.0 & 1.5 & 0.7 & 0.4 & $\begin{array}{l}\text { Structural } \\
\text { stubility }\end{array}$ & 1.0 & 4.0 & 1.0 & 1.5 & 0.7 & 0.5 \\
\hline Durability & 1.0 & 3.0 & 1.0 & 1.4 & 0.6 & 0.4 & Durability & 1.0 & 4.0 & 1.0 & 1.6 & 1.0 & 0.9 \\
\hline $\begin{array}{l}\text { Insulation from } \\
\text { rain }\end{array}$ & 1.0 & 3.0 & 1.0 & 1.3 & 0.6 & 0.3 & $\begin{array}{l}\text { Insulation from } \\
\text { rain }\end{array}$ & 1.0 & 3.0 & 1.0 & 1.4 & 0.5 & 0.3 \\
\hline Resistance to mold & 1.0 & 3.0 & 1.0 & 1.4 & 0.5 & 0.3 & $\begin{array}{l}\text { Resistance to } \\
\text { mold }\end{array}$ & 1.0 & 4.0 & 1.0 & 1.6 & 0.9 & 0.8 \\
\hline $\begin{array}{l}\text { Healthy inner } \\
\text { environment }\end{array}$ & 1.0 & 3.0 & 1.0 & 1.5 & 0.7 & 0.4 & $\begin{array}{l}\text { Healthy inner } \\
\text { environment }\end{array}$ & 1.0 & 3.0 & 1.0 & 1.4 & 0.7 & 0.4 \\
\hline Sustainability & 1.0 & 3.0 & 1.0 & 1.5 & 0.6 & 0.3 & Sustainability & 1.0 & 3.0 & 2.0 & 1.7 & 0.7 & 0.5 \\
\hline
\end{tabular}

\begin{tabular}{|c|c|c|c|c|c|c|c|c|c|c|c|c|c|}
\hline - & $\min$ & $\max$ & median & average & $\begin{array}{l}\text { Standard } \\
\text { Deviation }\end{array}$ & Variance & - & $\min$ & $\max$ & median & average & $\begin{array}{l}\text { Standard } \\
\text { Deviation }\end{array}$ & Variance \\
\hline $\begin{array}{l}\text { Wood creates a } \\
\text { confortable home }\end{array}$ & 1.0 & 4.0 & 2.0 & 1.8 & 0.9 & 0.9 & $\begin{array}{l}\text { Bricks, concrete, } \\
\text { etc. create a } \\
\text { confortable }\end{array}$ & 1.0 & 5.0 & 2.0 & 2.5 & 0.9 & \\
\hline environment & . & 箥 & 2.0 & 10 & . & . & $\begin{array}{l}\text { home } \\
\text { environment } \\
\text { Bricks, concrete, }\end{array}$ & . & .0 & 2.0 & 20 & . & \\
\hline $\begin{array}{l}\text { Wood ensures } \\
\text { thermal insulation }\end{array}$ & 1.0 & 5.0 & 3.0 & 2.8 & 1.3 & 1.6 & $\begin{array}{l}\text { etc. ensure } \\
\text { thermal } \\
\text { insulation } \\
\text { Bricks, concrete, }\end{array}$ & 1.0 & 5.0 & 3.0 & 2.9 & 1.2 & 1.5 \\
\hline $\begin{array}{l}\text { Wood ensures } \\
\text { acoustic insulation }\end{array}$ & 1.0 & 5.0 & 3.0 & 3.1 & 1.2 & 1.4 & $\begin{array}{l}\text { etc. ensure } \\
\text { acoustic } \\
\text { insulation }\end{array}$ & 1.0 & 5.0 & 3.0 & 2.9 & 1.2 & 1. \\
\hline $\begin{array}{l}\text { Wood ensures } \\
\text { structural stability }\end{array}$ & 1.0 & 5.0 & 3.0 & 2.8 & 1.1 & 1.1 & $\begin{array}{l}\text { Bricks, concrete, } \\
\text { etc. structural } \\
\text { stability }\end{array}$ & 1.0 & 4.0 & 2.0 & 2.2 & 1.2 & 1. \\
\hline
\end{tabular}




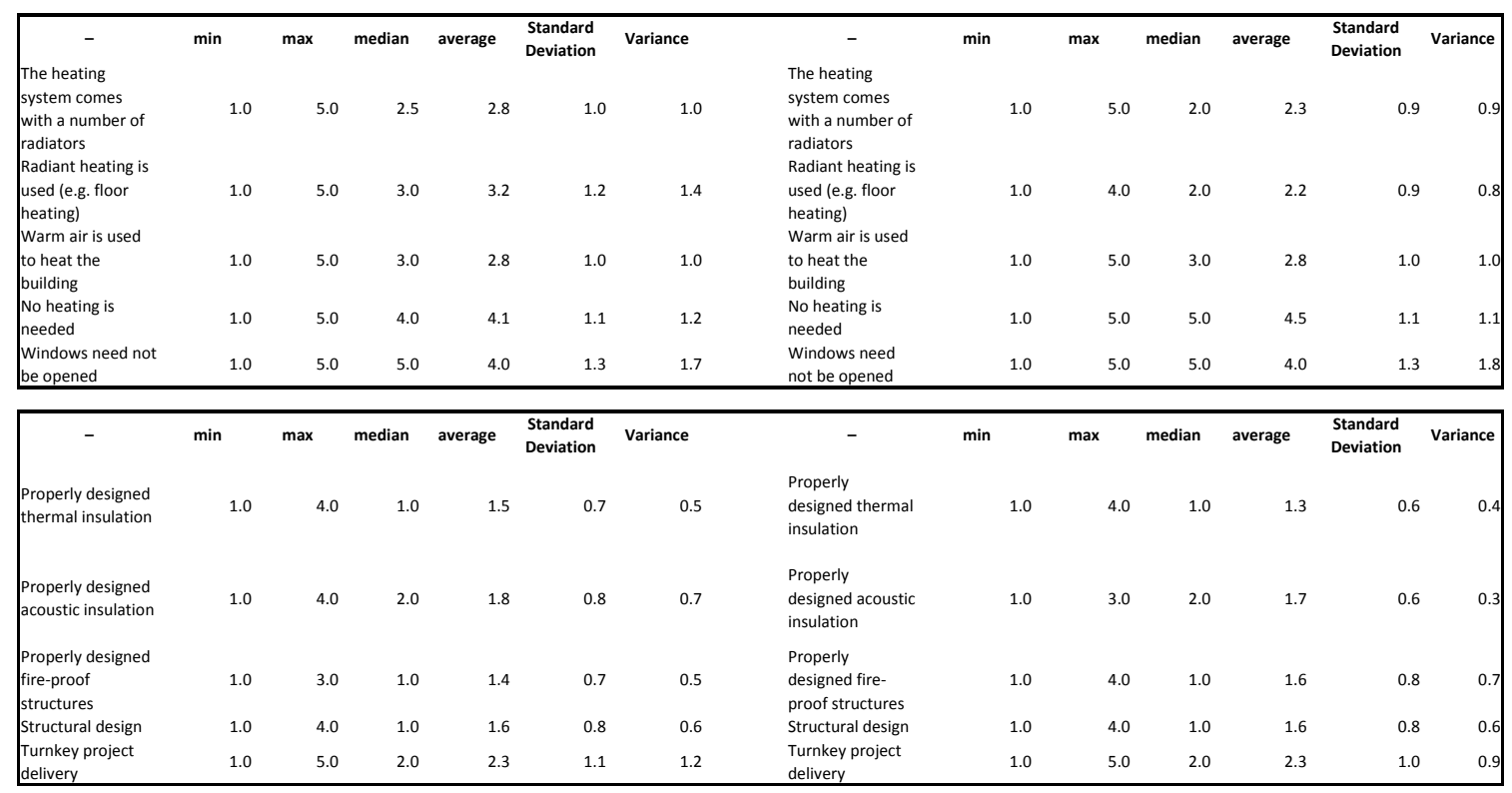

\section{References}

1. Available online: https://unfccc.int/process/the-kyoto-protocol (accessed on 25 July 2018).

2. Junggren, F.; Ågren, A. Potential solutions to improved sound performance of volume based lightweight multi-storey timber buildings. Appl. Acoust. 2011, 72, 231-240. [CrossRef]

3. Caniato, M.; Sbaizero, O.; Schmid, C.; Bettarello, F. Recycled materials for noise reduction in floating floors. In Proceedings of the 22nd International Congress on Sound and Vibration, Florence, Italy, 12-16 July 2015.

4. Ryu, J.; Sato, H.; Kurakata, K.; Hiramitsu, A.; Tanaka, M.; Hirota, T. Relation between annoyance and single-number quantities for rating heavy-weight floor impact sound insulation in wooden houses. J. Acoust. Soc. Am. 2011, 129, 3047-3055. [CrossRef] [PubMed]

5. Chung, H.; Fox, C.; Dodd, G.; Emms, G. Lightweight floor/ceiling systems with improved impact sound insulation. Build. Acoust. 2010, 17, 129-141. [CrossRef]

6. D'Amore, G.K.O.; Caniato, M.; Travan, A.; Turco, G.; Marsich, L.; Ferluga, A.; Schmid, C. Innovative thermal and acoustic insulation foam from recycled waste glass powder. J. Clean. Prod. 2017, 165, 1306-1315.

7. Mugoni, C.; Montorsi, M.; Siligardi, C.; Andreola, F.; Lancellotti, I.; Bernardo, E.; Barbieri, L. Design of glass foams with low environmental impact. Ceram. Int. 2015, 41, 3400-3408. [CrossRef]

8. Caniato, M.; Bettarello, F.; Longhi, S.; Sbaizero, O. Renovation of historic building for music rooms and recording studio: High acoustic and energetic performances. In Proceedings of the 39th International Congress on Noise Control Engineering, Lisbon, Portugal, 13-16 June 2010; Elsevier: Amsterdam, The Netherlands, 2010; pp. 6902-6908.

9. Kibert, C.; Srinivasan, R. Net zero: A novel approach for setting sustainability targets for built environment. Adv. Build. Sci. 2013, 11-28.

10. McCarthy, T.J.; Rasekth, H. 21st century sustainable building design in Australia. Adv. Build. Sci. 2013, 13, 51-65.

11. Schiavoni, S.; Bianchi, F.; Asdrubali, F. Insulation materials for the building sector: A review and comparative analysis. Renew. Sustain. Energy Rev. 2016, 62, 988-1011. [CrossRef]

12. Asdrubali, F.; Schiavoni, S.; D'Alessandro, F. A review of unconventional sustainable building insulation material. Sustain. Mater. Technol. 2015, 4,1-17. [CrossRef]

13. Bribian, I.Z.; Capilla, A.V.; Aranda Urison, A. Life cycle assessment of building materials: Comparative analysis of energy and environmental impacts and evaluation of the eco-efficiency improvement potential. Build. Environ. 2011, 46, 1133-1140. [CrossRef]

14. Caniato, M.; Bettarello, F. The impact of acoustics and energy efficiency protocols on comfort in the building industry. Open J. Civ. Eng. 2013, 3, 40-45. [CrossRef] 
15. Lang, S.W. Progress in energy-efficiency standards for residential buildings in China. Energy Build. 2004, 36, 1191-1196. [CrossRef]

16. Nguyen, B.K.; Altan, H. Comparative review of five sustainable rating systems. Procedia Eng. 2011, 21, 376-386. [CrossRef]

17. Available online: https://new.usgbc.org/leed (accessed on 25 July 2018).

18. Ramage, M.H.; Burridge, H.; Busse-Wicher, M.; Fereday, G.; Reynolds, T.; Shah, D.U.; Wu, G.; Yu, L.; Fleming, P.; Densley-Tingley, D.; et al. The wood from the trees: The use of timber in construction. Renew. Sustain. Energy Rev. 2017, 68(Part 1), 333-359. [CrossRef]

19. Forest Products Laboratory (United States Department of Agriculture). Wood Handbook-Wood as an Engineering Material; Centennial Edition: Madison, WI, USA, 2010.

20. Telandersson, S.; Larsen, H.J. Timber Engineering; Wiley: Chichester, UK, 2003.

21. COST Action FP0702. Net-Acoustics for Timber Based Lightweight Buildings and Elements, eBook. 2014. Available online: http://extranet.cstb.fr/sites/cost/ebook/Forms/AllItems.aspx (accessed on 11 February 2019).

22. Bettarello, F.; Fausti, P.; Baccan, V.; Caniato, M. Impact sound pressure level performances of basic beam floor structures. Build. Acoust. 2010, 17, 305-316. [CrossRef]

23. Ver, I.L. Impact noise isolation of composite floors. J. Acoust. Soc. Am. 1971, 50, 1043-1050. [CrossRef]

24. Gerretsen, E. Predicting the sound reduction of building elements from material data. Build. Acoust. 1999, 6, 225-234. [CrossRef]

25. Pajek, L.; Hudobivnik, B.; Kunič, R.; Košir, M. Improving thermal response of lightweight timber building envelopes during cooling season in three European locations. J. Clean. Prod. 2017, 156, 939-952. [CrossRef]

26. Pernigotto, G.; Prada, A.; Patuzzi, F.; Baratieri, M.; Gasparella, A. Characterization of the dynamic thermal properties of the opaque elements through experimental and numerical tests. Energy Procedia 2015, 78, 3234-3239. [CrossRef]

27. Jorissen, A.; Leijten, A.J.M. Tall Timber Buildings in The Netherlands. Struct. Eng. Int. 2008, 18, $133-136$. [CrossRef]

28. Abeysekera, I.; Málaga-Chuquitaype, C. Dynamic response of tall timber buildings. In Proceedings of the SECED 2015 Conference: Earthquake Risk and Engineering Towards a Resilient WorldAt, Cambridge, UK, 9-10 July 2015.

29. Kuzmanovska, I.; Gasparri, E.; Monne, D.T.; Aitchison, M. Tall timber buildings: Emerging trends and typologies. In Proceedings of the World Conference on Timber Engineering (WCTE 2018), Seoul, Korea, 20-23 August 2018.

30. Caniato, M.; Bettarello, F.; Fausti, P.; Ferluga, A.; Marsich, L.; Schmid, C. Impact sound of timber floors in sustainable buildings. Build. Environ. 2017, 120, 110-122. [CrossRef]

31. Caniato, M.; Bettarello, F.; Ferluga, A.; Marsich, L.; Schmid, C.; Fausti, P. Acoustic of lightweight timber buildings: A review. Renew. Sustain. Energy Rev. 2017, 80, 585-596. [CrossRef]

32. Di Monte, R.; Caniato, M.; Boscarato, I.; Kaspar, J.; Sbaizero, O. Green cork-based innovative resilient and insulating materials: Acoustic, thermal and mechanical characterization. Proc. Meet. Acoust. 2013, 19, 040096.

33. Yuan, J.; Farnham, C.; Emura, K. Optimum insulation thickness for building exterior walls in 32 regions of China to save energy and reduce $\mathrm{CO}_{2}$ emissions. Sustainability 2017, 9, 1711. [CrossRef]

34. Dombayc1, Ö.A. Investigation of the effect of thermal insulation for a model house in cold regions: A case study of Turkey. Environ. Prog. Sustain. Energy 2013, 33, 527-537. [CrossRef]

35. Ljunggren, F.; Ågren, A. How to match building acoustic measurements with subjective judgements? In Proceedings of the Internoise, New York, NY, USA, 19-22 August 2012.

36. Ljunggren, F; Backman, E. Data from Building Acoustic Measurements and Questionnaire Survey in Multi-Family Houses. Akulite Report 8, LTU Report 2013, SP Report 2013: 10. 2013. Available online: http://ri.diva-portal. org/smash/get/diva2:962797/FULLTEXT01.pdf (accessed on 13 April 2019).

37. Adeyeye, K.; Osmani, M.; Brown, C. Energy conservation and building design: The environmental legislation push and pull factors. Struct. Surv. 2007, 5, 55-57. [CrossRef]

38. Praznik, M.; Butala, V.; Zbašnik-Senegačnik, M. Simplified evaluation method for energy efficiency in single-family houses using key quality parameters. Energy Build. 2013, 67, 489-499. [CrossRef]

39. Lee, W.; Kim, K.; Lim, S. Improvement of floor impact sound on modular housing for sustainable building. Renew. Sustain. Energy Rev. 2014, 29, 263-275. [CrossRef] 
40. Di Bella, A.; Fausti, P.; Scamoni, F.; Secchi, S. Italian experiences on acoustic classification of buildings. In Proceedings of the Internoise, New York, NY, USA, 19-22 August 2012.

41. Caniato, M.; Bettarello, F.; Taffarel, M. Sound power level of speaking people. In Proceedings of the Meetings on Acoustics, Montreal, QC, Canada, 2-7 June 2013.

42. Sant'Anna, D.O.; Santos, P.H.D.; Vianna, N.S.; Romero, M.A. Indoor environmental quality perception and users' satisfaction of conventional and green buildings in Brazil. Sustain. Cities Soc. 2018, 43, 95-110. [CrossRef]

43. Leaman, A.; Bordass, B. Are users more tolerant of "green" buildings? Build. Res. Inf. 2007, 35, 662-673. [CrossRef]

44. Park, S.-Y.; Cho, S.; Ahn, J. Improving the quality of building spaces that are planned mainly on loads rather than residents: Human comfort and energy savings for warehouses. Energy Build. 2018, 178, 38-48. [CrossRef]

45. Pisello, A.L.; Asdrubali, F. Human-based energy retrofits in residential buildings: A cost-effective alternative to conventional physical strategies. Appl. Energy 2014, 133, 224-235. [CrossRef]

46. Available online: www.scopus.com (accessed on 6 October 2018).

47. Available online: https://scholar.google.it (accessed on 6 October 2018).

48. Diaz Lozano Patino, E.; Siegel, J.A. Indoor environmental quality in social housing: A literature review. Build. Environ. 2018, 131, 231-241. [CrossRef]

49. Gupta, R.; Chandiwala, S. Understanding occupants: Feedback techniques for large-scale low-carbon domestic refurbishments. Build. Res. Inf. 2010, 38, 530-548. [CrossRef]

50. Isaacs, N.; Saville-Smith, K.; Camilleri, M.; Burrough, L. Energy in New Zealand houses: Comfort, physics and consumption. Build. Res. Inf. 2010, 38, 470-480. [CrossRef]

51. Zhang, Y.; Wang, J.; Chen, H.; Zhang, J.; Meng, Q. Thermal comfort in naturally ventilated buildings in hot-humid area of China. Build. Environ. 2010, 45, 2562-2570. [CrossRef]

52. Castaldo, V.L.; Pigliautile, I.; Rosso, F.; Cotana, F.; de Giorgio, F.; Pisello, A.L. How subjective and non-physical parameters affect occupants' environmental comfort perception. Energy Build. 2018. [CrossRef]

53. Yang, B.; Olofsson, T.; Wang, F.; Lu, W. Thermal comfort in primary school classrooms: A case study under subarctic climate area of Sweden. Build. Environ. 2018, 135, 237-245. [CrossRef]

54. Kotopouleas, A.; Nikolopoulou, M. Evaluation of comfort conditions in airport terminal buildings. Build. Environ. 2018, 130, 162-178. [CrossRef]

55. Gou, Z.; Prasad, D.; Lau, S.S.Y. Are green buildings more satisfactory and comfortable? Habitat Int. 2013, 39, 156-161. [CrossRef]

56. Paul, W.L.; Taylor, P.A. A comparison of occupant comfort and satisfaction between a green building and a conventional building. Build. Environ. 2008, 43, 1858-1870. [CrossRef]

57. Li, P.; Froese, T.M.; Brager, G. Post-occupancy evaluation: State-of-the-art analysis and state-of-the-practice review. Build. Environ. 2018, 133, 187-202. [CrossRef]

58. Schwarz, N.; Oyserman, D. Asking questions about behaviour: Cognition, communication, and questionnaire construction. Am. J. Eval. 2001, 22, 127-160. [CrossRef]

59. Schwarz, N. Self-reports: How the questions shape the answers. Am. Psychol. 1999, 54, 93-105. [CrossRef]

60. Hjermstad, M.J.; Fayers, P.M.; Haugen, D.F.; Caraceni, A.; Hanks, G.W.; Loge, J.H.; Fainsinger, R.; Aass, N.; Kaasa, S. Studies comparing numerical rating scales, verbal rating scales, and visual analogue scales for assessment of pain intensity in adults: A systematic literature review. J. Pain Symp. Manag. 2011, 41, 1073-1093. [CrossRef] [PubMed]

61. Burns, A.C.; Bush, R.F.; Nash, J. Basic Marketing Research: Using Microsoft Excel Data Analysis; Pearson Prentice Hall: Upper Saddle River, NJ, USA, 2008.

62. Bettarello, F.; Caniato, M.; Monte, R.D.; Kaspar, J.; Sbaizero, O. Preliminary Acoustic tests on resilient materials: Comparison between common layers and nanostructured layers. In Proceedings of the 20th International Congress on Acoustics 2010, Sydney, Australia, 23-27 August 2010; Volume 2, pp. 1096-1101.

63. Caniato, M.; Bettarello, F.; Ferluga, A.; Marsich, L.; Schmid, C.; Fausti, P. Thermal and acoustic performance expectations on timber buildings. Build. Acoust. 2017, 24, 219-237. [CrossRef]

64. Zagreus, L.; Huizenga, C.; Arens, E.; Lehrer, D. Listening to the occupants: A web-based indoor environmental quality survey. Indoor Air 2004, 14, 65-74. [CrossRef] [PubMed]

65. Bryman, A. Social Research Methods, 2nd ed.; Oxford University Press: Oxford, UK, 2004. 
66. Fink, A. How to Conduct Surveys: A Step-by-Step Guide, 3rd ed.; Sage: London, UK, 2005.

67. Heerwagen, J.; Zagreus, L. The Human Factors of Sustainable Building Design: Post Occupancy Evaluation of the Philip Merrill Environmental Center; Center for the Built Environment: Berkeley, CA, USA, 2005.

68. Tavakol, M.; Dennick, R. Making sense of Cronbach's alpha. Int. J. Med. Educ. 2011, 2, 53-55. [CrossRef]

69. Miller, M.B. Coefficient alpha: A basic introduction from the perspectives of classical test theory and structural equation modeling. Struct. Equ. Model. Multidiscip. J. 1995, 2, 255-273. [CrossRef]

70. Yamtraipat, N.; Khedari, J.; Hirunlabh, J. Thermal comfort standards for air conditioned buildings in hot and humid Thailand, considering additional factors of acclimatization and education level. Sol. Energy 2005, 78, 504-517. [CrossRef]

71. Luo, M.; Arens, E.; Zhang, H.; Ghahramani, A.; Wang, Z. Thermal comfort evaluated for combinations of energy-efficient personal heating and cooling devices. Build. Environ. 2018, 143, 206-216. [CrossRef]

72. Fowler, F.J. Survey Research Methods, 3rd ed.; Sage: London, UK, 2001.

73. Mahbob, N.S.; Kamaruzzaman, S.N.; Salleh, N.; Sulaiman, R. Correlation and regression studies of indoor environmental quality (IEQ), human productivity, comfort and stress level in office buildings. Adv. Sci. Lett. 2013, 19, 342-345. [CrossRef]

74. Firth, S.K.; Lomas, K.J.; Wright, A.J. Targeting household energy-efficiency measures using sensitivity analysis. Build. Res. Inf. 2009, 38, 25-41. [CrossRef]

75. Steemers, K.; Yun, G.Y. Household energy consumption: A study of the role of occupants. Build. Res. Inf. 2009, 37, 625-637. [CrossRef]

76. Caniato, M.; Bettarello, F.; Schmid, C.; Fausti, P. The use of numerical models on service equipment noise prediction in heavyweight and lightweight timber buildings. Build. Acoust. 2019, 26, 35-55. [CrossRef]

(C) 2019 by the authors. Licensee MDPI, Basel, Switzerland. This article is an open access article distributed under the terms and conditions of the Creative Commons Attribution (CC BY) license (http://creativecommons.org/licenses/by/4.0/). 